\title{
Campus Hate Speech Codes: Affirmative Action in the Allocation of Speech Rights
}

\author{
Alice K. Ma†
}

The now-familiar debate over regulating hate speech on college and university campuses has pitted the values of the First Amendment against those of the Fourteenth. Proponents of hate speech codes focus on the equality principle, arguing that it outweighs freedom of speech. Opponents of speech regulation rely on the privileged position of the First Amendment and claim that speech codes would harm rather than benefit equality. This debate is doomed to end in stalemate since scholars will always differ over the normative question of whether freedom of speech or the equality guarantee is more crucial. Approaching the debate from a different perspective, this Comment argues that the two principles can be harmonized by recognizing that free speech is illusory unless each individual has an equal opportunity to speak. Furthermore, this Comment argues that speech rights are distributed unequally in American society because hate speech silences minority voices. Hate speech codes on college campuses would remedy present and past discrimination in speech rights just as affirmative action programs remedy past discrimination in hiring, university admissions, and public works. Viewing hate speech regulation as a type of affirmative action reveals that such regulation serves not only equality interests, but speech interests as well. By regulating speech that silences students of color, colleges and universities can foster greater freedom of speech overall. This Comment uses the principles and doctrine of affirmative action law to analyze hate speech regulation. The author argues that treating such regulations as affirmative action programs and applying equal protection law demonstrates their validity under both the First and the Fourteenth Amendments. The Comment concludes with some thoughts on the ways in which these two amendments interact, and why it is appropriate to consider the First Amendment in light of the Fourteenth.

Copyright $\odot 1995$ California Law Review, Inc.

$\dagger$ A.B. 1989, Harvard and Radcliffe Colleges; J.D. candidate 1995, Boalt Hall School of Law, University of California, Berkeley. 1 would like to thank Professor Jesse H. Choper, who critiqued drafts of this Comment. All mistakes are my own. Special thanks to the staff of the California Law Review, especially David King, Melissa Dawson, Ed Adams, Jessica Karner, Jackie Piscitello, and Karen Fass. This Comment is dedicated to my husband, Joe Hayashi, and to my parents, Jimmy and Lily Ma. 


\section{INTRODUCTION}

By now, the litany of abuses is perliaps a little worn. In every article and discussion on campus hate speech, scholars cite similar incidents. The affair at The Citadel, for example, is notorious: In October 1986, five hooded figures clothed in white sheets burst into the room of a sleeping cadet. They clianted the cadet's name, yelled obscenities, and deposited a cliarred cross in the room. They were white; lie was African American. ${ }^{1}$

Racist, sexist, and hontophobic incidents do not occur only at conservative, military institutions such as The Citadel, and they have not abated despite the volumes of scholarship in recent years. In mid-Deceniber 1994, at the University of California at Berkeley's Boalt Hall Scliool of Law, anonymous fiyers making derogatory racial references were distributed to the inailboxes of some first-year students immediately before their first law school examination. ${ }^{2}$ Dean Hernia Hill Kay proniptly condemned the hate mail and called a "town hall meeting" to discuss the incident. In midFebruary, lowever, first-year students of color discovered more flyers. They read, in part:

Rejoice you cry baby Niggers it's affirmative action nontli. A town hall meeting will not save you the wetbacks or the chinks. Your failures are liereditary and can't be corrected by these liberals. Look around Boalt Hall besides the few hand picked affirmative action professors this is a quality law school.... When I see you in class it bugs the hell out of me because your taking the seat of soineone qualified. You belong at Coolie High Law don't you forget! ${ }^{3}$

About the same time, in December 1994, at a canipus of Colorado's Metropolitan State College, a group called Students Against the Brown Peril distributed a handbill with the headline "Stop the Mexican Invasion."4

In Rhode Island, Brown University lias established a cantpus hotline in response to an outbreak of racial incidents. The school offers $\$ 1,000$ for

1. Richard Delgado, Campus Antiracism Rules: Constitutional Narratives in Collision, $85 \mathrm{Nw}$. U. L. Rev. 343, 349 (1991) [hereinafter Delgado, Campus Antiracism Rules].

2. Memorandum from Hcrma Hill Kay, Dean, Boalt Hall School of Law, to the Boalt Hall Community (Dec. 13, 1994) (on file with author). Two separate flyers were distributed. One featured the slogan "MONKEYS BELONG IN THE JUNGLE!!" The other declared, "AFFIRMATIVE ACTION SUCKS!!! DON'T FLUNK OUT!!!" (On flle with the Boalt Hall administration.)

3. The text of the hate mail is contained in a flycr distributed to the Boalt Hall community by the Law Students of African Descent immediately following the appearance of the hate mail (Feb. 13, 1995) (on file with the author). The text has not been corrected for punctuation or grammar.

Numerous students, student organizations, professors, administrators, staff members, and community members immediately denounced the hate mail and expressed their support for diversity at the school and their condemnation of the hate mail. See, e.g., Open Lettcr to the Boalt Community from Dean Herma Hill Kay (Feb. 13, 1995) (on file with author); Statement of Boalt Hall Faculty and Staff Concerning the Recent Hate Mail (Feb. 14, 1995) (on flle with author).

4. Sue Lindsay and Gary Massaro, Auraria Vows Investigation into Racist Fliers on Campus, Rocky MountaIn News, Dec. 3, 1994, at A4. 
information leading to an arrest. As of mid-December, the latest mcident was the scrawling of a racial epithet across a dormitory bathroom mirror. ${ }^{5}$

In the spring of 1994, at Stanford University, several student athletes were arrested for splattering the school's "Gay Liberation" statue with black acrylic paint and ramming the statue with a wooden bench, which they left wedged between the figures of two standing gay men. The bronze statue, the nation's first public monument to gays and lesbians, has been vandahized several times. ${ }^{6}$

Like all problems of hatred and intolerance among diverse groups, the problein of hate speech seems as insoluble as ever. The debate over whether colleges and universities should prohibit such speech has reached a staleinate. The opposing camps have arrayed theniselves around either the First Amendinent's protection of free speech or the Fourteenth Amendment's guarantee of equal protection. On one side, an unlikely coalition of civil hibertarians and nore traditional legal scholars argue forcefully that one ill-defined exception to free speech will lead to another and yet another, that government censorship is inherently dangerous, and that the distinction between speech and conduct has so far served us well. ${ }^{7}$ On the other side, proponents of critical legal theory, focusing on the perspective of the victim, the inequities in the marketplace of ideas, and the harm to both individuals and society, reject the contention that hate speech regulation violates the First Amendinent. ${ }^{8}$

5. Across the USA: News from Every State, USA TodAY, Dec. 14, 1994, at 10A. at A15.

6. Bill Workman, 7 Stanford Athletes Arrested in Vandalism Case, S.F. CHroN., May 18, 1994,

7. See, e.g., Kenneth L. Karst, Boundaries and Reasons: Freedom of Expression and the Subordination of Groups, 1990 U. IrL. L. REv. 95 (defending First Amendment protection of speech that falls outside the "civic deliberation" model); Calvin R. Massey, Hate Speech, Cultural Diversity, and the Foundational Paradigms of Free Expression, 40 UCLA L. REv. 103, 197 (1992) (arguing that hate speech regulations, "[t]hough undoubtedly well-meaning," threaten the "slow erosion of the pillars upon which autonomous self-governance has been erected"); Robert C. Post, Racist Speech, Democracy, and the First Amendment, 32 WM. \& MARY L. REv. 267, 325, 327 (1991) (asserting that advocates of hate speech codes in public discourse must either (1) articulate a more attractive vision of democracy not grounded in deliberative self-determination or (2) justify "suspensions of our fundamental democratic commitments," and suggesting that the constitutionality of hate speech codes on campus depends on how we characterize the educational purposes of public colleges and universities); Nadine Strossen, Regulating Racist Speech on Campus: A Modest Proposal?, 1990 Duke L.J. 484 (maintaining that eqnality is best served by robust speech rights).

8. See, e.g., Delgado, Campus Antiracism Rules, supra note 1 (claiming that speech regulation need not offend the First Amendment); Richard Delgado, Words That Wound: A Tort Action for Racial Insults, Epithets, and Name-Calling, 17 HARv. C.R.-C.L. L. Rev. 133 (1982) [hereinafter Delgado, Words That Wound] (arguing that an independent tort action for racial insults is not only permissible but necessary); Charles R. Lawrence, III, Crossburning and the Sound of Silence: Antisubordination Theory and the First Amendment, 37 VIIL. L. REV. 787 (1992) [hereinafter Lawrence, Crossburning] (criticizing the Supreme Court's decision in R.A.V. v. City of St. Paul, 112 S. Ct. 2538 (1992)); Charles R. Lawrence, III, If He Hollers Let Him Go: Regulating Racist Speech on Campus, 1990 Duke L.J. 431, 437 [hereinafter Lawrence, If He Hollers] (arguing that First Amendment values are frustrated by "an interpretation that is acontextual and idealized"); Mari J. Matsuda, Public Response to Racist Speech: Considering the Victim's Story, 87 Mrck. L. Rev. 2320 (1989) (demanding criminal as well as civil sanctions for hate speech and emphasizing the victims' stories). 
Pitting the First Amendment against the Fourteenth has not yielded a convincing solution to the hate speech question, however. ${ }^{9}$ This Comment suggests a different perspective. It argues that freedom of speech can be reconciled with equality for all only by acknowledging that free speech is illusory unless each individual has equal opportunity to speak. However, American society is no more equal in its distribution of speech rights than it is in hiring, university admissions, and other areas. By intimidating and silencing members of traditionally disadvantaged groups, hate speech ${ }^{10}$ discriminates against the speech rights of these people in the same way that segregatiomist policies have discriminated against them in other, more tangible ways.

Just as affirmative action programs remedy past discrimination in other areas in order to ensure present equality, so too hate speech codes would reinedy past discrimination in speech rights to ensure present and future equality of speech. The United States Supreme Court has ruled that affirmative action programs surviving strict scrutiny are constitutional under the Equal Protection Clause. ${ }^{11}$ In remedying inequities in the allocation of speech rights, hate speech codes would have the same function as affirmative aetion programs and would be just as constitutional.

Part I of this Comment briefly frames the canipus hate speech controversy and considers why hate speech at colleges and universities is particularly disturbing. Part II discusses the harm caused by hate speech and the urgent need for a remedy, arguing that the Supreme Court's invalidation of a hate crines ordinance in R.A.V. v. City of St. Paul ${ }^{12}$ neglected the issue of injury to hate speech victims. Part III provides a brief overview of affirmative action law in hiring, admissions, public works projects, and other familiar contexts. Part IV applies the analytical franework developed in Part III to university hate speech regulations. Treating such regulations as affirmative action programs and considering thein under equal protection law denionstrates their validity under both the First and Fourteenth

9. Professor Delgado suggests that in the end judges must simply choose one or the other. Delgado, Campus Antiracism Rules, supra note 1, at 383.

10. Although the term "hate speech" may refer to sexist and homophobic speech, as well as speech against religious and other minorities, this Comment uses the term to rcfer primarily to racist speech. Women and nonracial minorities deserve no less legal protection from verbal assault than people of color. However, this Comment focuses only on racist speech, with the hope that its thesis may be applied by analogy to other forms of hate speech.

11. See, e.g., Fullilove v. Klutznick, 448 U.S. 448 (1980) (upholding minority set-asides in federal publie works projects); United Jewish Orgs., Inc. v. Carey, 430 U.S. 144 (1977) (permitting raceconscious reapportionment in compliance with the Voting Rights Act of 1965); Swann v. CharlotteMecklenburg Bd. of Educ., 402 U.S. 1 (1971) (allowing the use of racial ratios as a starting point in school desegregation); $c f$. City of Richmond v. J.A. Croson Co., 488 U.S. 469 (1989) (finding that cityimplemented affirmative action programs must pass strict scrutiny and striking down a minority setaside plan that did not do so).

The Equal Protection Clause provides, "No state shall ... . deny to any person within its jurisdiction the equal protection of the laws." U.S. ConST. amend. XIV, $\S 1$.

12. 112 S. Ct. 2538 (1992). 
Amendments. Lastly, Part $\mathrm{V}$ examines how these two amendments interact with each other, and why it is appropriate to consider the First Amendment in light of the Fourteenth.

In grounding hate speech regulations in an affirmative action rationale, this Comment seeks to lend such regulations the legitimacy of affirmative action programs. As one journalist notes, attacking affirmative action programs used to be "political poison."13 As of this writing, however, critics have commenced a broad-based assault on affirmative action programs. In California, for example, Assemblyman Bernie Richter has proposed a state constitutional amendment that would prohibit the use of race, sex, color, ethnicity, or national origin as criteria for either discrimination or preferential treatment in the public sector. ${ }^{14}$ Richter has also submitted four bills that would eliminate affirmative action programs for public contracting, employment, university hiring, and university enrollment. ${ }^{15}$

Affirmative action programs in California may be threatened even if these legislative efforts fail. The California Civil Rights Initiative, which supporters plan to place on the 1996 ballot, would forbid state and local governments and state universities from giving preferential treatment on the basis of race, ethnicity, or gender in hiring, contracting, and admissions. ${ }^{16}$ Furthermore, the initiative's supporters hope to use California as "a springboard for a national crusade."17 There is criticisin of preferential treatment from within the University of California systen 1 as well. Regent Ward Connerly has proposed that the U.C. system set a date near the end of the century by which affirmative action as it now exists would end. ${ }^{18}$

Most important for the purposes of this Comment, the United States Supreme Court is expected to hand down a decision in the summer of 1995 that may have widespread repercussions for affirmative action programs. In Adarand Constructors, Inc. v. Pena, the Court will consider, among otler issues, whether intermediate scrutimy remains the proper standard for evaluating the constitutionality of raced-based programs adopted by Congress. ${ }^{19}$ If the Court decides that strict rather than internediate scrutiny is required, its holding would necessarily imply strict scrutiny of hate speech regulations based on an affirmative action rationale. However, the holding would have no effect on the ultimate conclusion of this Comment: When analyzed

13. Yumi Wilson, Affirmative Action Fight Heats Up; Measures Would End State Programs, S.F. Chron., Jan. 26, 1995, at Al, A13.

14. Id.

15. Id.

16. George Skelton, Affirmative Action Issue: Another 187?, L.A. TIMES, Feb. 2, 1995, at A3.

17. Id.

18. Richard Bernstein, Moves Under Way in California to Overturn Higher Education's Affirmative Action Policy, N.Y. Tmes, Jan. 25, 1995, at B8.

19. 16 F.3d 1537 (10th Cir.), cert. granted, 115 S. Ct. 41 (1994) (No. 93-1841) (involving a reverse discrimination challenge to a federal minority set-aside program).

On the distinction between strict scrutiny and intermediate scrutiny, see infra notes 91,101 and accompanying text. 
as a form of affirmative action, hate speech regulations are constitutional even under the strict scrutiny standard..$^{20}$

The constitutionality of campus hate speech codes may prove to be no defense, however, if public opinion turns agamst them in the same way that it seems to be turning against affirmative action programs in Califorma. Only time will reveal the resolution of those battles.

Supplying an affirmative action rationale for hate speech codes is unorthodox. Critics will argue that I confuse rights with liberties and equality with freedoin, but viewing First Amendment free speech rights through a Fourteenth Amendment prism may yield some insight into the hate speech controversy. The constitutionality and desirability of hate speech codes pose seemingly intractable dilemmas. Ultimately, the solution lies not in legal reform but in societal transformation. Toward that end, there must be inany starting points, of which, I hope, this is one.

\section{I}

Framing the Debate: College-Level Racism and Hate SPEECH

The sordid underside of diversity is bigotry. As the econoiny has faltered, immigration increased, and cultural differences inultiplied, intolerance has proliferated in forms both elusive and blatant. Among other events, the 1992 Rodney King riots, Amita Hill's testimony at Justice Clarence Thoinas' confirmation hearing, and the passage of Proposition 187 in California ${ }^{21}$ remmd us that America has not yet reconciled itself to the coinposition of its populace.

It should not be surprising, therefore, that hate crime and hate speech permeate the nation's universities and colleges. The Chronicle of Higher

20. See infra Part IV.B. In Part IV.A.1, this Comment argues that federally mandated hate speech regulations might be subject only to intermediate scrutiny because federally mandated affirmative action programs have been subject, thus far, only to intermediate scrutiny. For unique reasons, however, hate speech codes may qualify for intermediate scrutiny even if the Court decides to subject their affirmative action counterparts to strict scrutiny. See infra Part IV.A.2.

2I. Described by the Los Angeles Times as the year's "eleetoral lightuning rod," Proposition 187 prohibits state and local governments from providing education, nonemergency medical care, and other social services to illegal immigrants. Maria L. La Ganga, Prop. 187, Heated Races Boost Voter Turnout in State, L.A. Tmes, Nov. 9, 1994, at A3; You May Be Surprised at Who's Against Prop. 187; Conservative, Business, Police Leaders See Measure as a Grave Mistake, L.A. TnMEs, Nov. 6, 1994, at B20. This so-called "Save Our State" initiative requires state and local agencies to report "apparent illegal aliens" to immigration authorities. Id. Opponents of Proposition 187 characterize it as racist and divisive. See, e.g., Efrain Hernandez, Jr., Point of Impact, L.A. Tmes, Nov. 6, 1994, City Times (magazine), at 14 (reporting discrimination concerns of opponents to Proposition 187). After approval of Proposition 187 by $59 \%$ of Califomia voters in November 1994, the battle over its validity has shifted to the courtroom. Paul Feldman \& Amy Pyle, Wilson Acts to Enforce Parts of Prop. 187: Eight Lawsuits Filed, L.A. TMms, Nov. 10, 1994, at A1. Meanwhile, key sponsors of the ballot measure have been deluged by phone calls from grass-roots groups hoping to get similar legislation passed in their own states. Paul Feldman \& Patrick J. McDonnell, Prop. 187 Sponsors Swept Up in National Whirlwind; Immigration: Callers Seek Help in Carrying Effort to Other States, L.A. TIMEs, Dec. 14, 1994, at Al. 
Education reported in 1990 that roughly 250 colleges and universities had experienced serious racist incidents since 1986.22 Approximately twentyfive percent of all students of color are victimized at least once during an academic year. ${ }^{23}$ These figures do not account for the estimated forty to fifty percent of racist incidents that are never reported. ${ }^{24}$

Perhaps the high nuniber of racist episodes on campus inakes perverse sense. One study shows that at least half the people arrested for hate crimes are between the ages of sixteen and twenty-five. ${ }^{25}$ In addition, hate crimes are now more often perpetrated by imdividuals and sinaller groups rather than by orgamizations like the $\mathrm{Ku}$ Klux Klan. ${ }^{26}$

Nonetheless, intolerance in our cducational institutions is particularly discouraging. The major turning point of the civil rights movement, Brown v. Board of Education, ${ }^{27}$ is only one emblem of our faith in education as the key to a greater understanding and appreciation of diversity, as well as increased political and economic opportunity. Although Brown involved primary and secondary schools, its reasoning apphes with equal force to public postsecondary education:

[E]ducation is perhaps the most important function of state and local governments .... It is the very foundation of good citizenship. Today it is a principal instrument in awakening the child to cultural values, in preparing him for later professional training, and in helping him to adjust normally to his environment ... . Such an opportumity, where the state has undertaken to provide it, is a right which inust be inade available to all on equal terms. ${ }^{28}$

We expect college students to be enlightened and inore tolerant. If we cannot escape racisin, sexisin, or homophobia at an elite university, then where else?

In the context of hate speech regulation, however, this ideal of the enlightened, tolerant university collides violently with another, equally compelhing vision - the ideal of the university as the paradiginatic "inarketplace of ideas." Justice Holmes coined this phrase seventy-six years ago to describe a First Amendinent theory that allows all speech so long as it does not constitute a "present danger of immediate evil or an intent to bring it

22. Lawrence, Crossburning, supra note 8, at 793 (citing Howard J. Uhrlich, Campus Ethnoviolence and the Policy Options, 4 Nat'l Inst. Aganst Prejudice \& Violence iii (1990)).

23. Id.

24. Susan M. Finegan, Note, Anti-Harassment Disciplinary Policies: A Violation of First Amendment Rights on the Public University Campus?, 11 B.C. THRD WORLD L.J. 107, 108 (1991).

25. Peter finn \& Taylor McNem, The Response of the Crmmanal Justice System to Bias CRIME: AN Exploratory ReVIEW 1 (1987).

26. Id.

27. 347 U.S. 483 (1954); see also United States v. Fordice, 112 S. Ct. 2727 (1992) (reaffirming that states have an affirmative duty to dismantle segregated public university systems, whether segregation is de facto or de jure).

28. Brown, 347 U.S. at 493 (emphasis added). 
about." ${ }^{\text {29 }}$ Relying on the action of time and truth rather than censorship, Justice Holmes foresaw the preeminence that has since been accorded freedom of speech. Henry Louis Gates, Jr. has called our commitment to frce speech "the central article of faith in the civil religion of America."30

If colleges and universities are repositories of knowledge and truth, however defined, then they should particularly value open dialogue. Our ideal of free speech informs our ideal of tolerance: true diversity necessarily encompasses all ideas. But is this true even when a speaker, such as a $\mathrm{Ku}$ Klux Klan member, is defined by the harm he accomplishes and the fear he instills? Is the First Amendment truly so broad-and the Constitution so narrow- that even hate speech is protected? The rest of this Comment contends that neither the First nor the Fourteenth Amendments requires that we permit the racist taunts, slurs, and graffiti that have proliferated at colleges and universities. The inequality worked by hate speech is as repugnant to the one amendment as it is to the other.

\section{III}

\section{Will the Real Victim Please Stand?}

In analyzing hate speech codes, critical race theorists have focused attention on the injuries inflicted on hate speech victims. ${ }^{31}$ Similarly, proponents of affirmative action programs have grounded such programs in past discrimination. ${ }^{32}$ This Part first discusses the Supreine Court's failure to acknowledge harm as a factor in R.A.V. v. City of St. Paul. ${ }^{33}$ It then explores the nature and extent of the harm suffered by hate speech victims and concludes that this significant harm justifies hate speech regulation.

\section{A. R.A.V.: Half of the Story}

In the suminer of 1992, the Supreme Court handed down its inost significant hate speech decision to date, R.A.V. v. City of St. Paul. ${ }^{34}$ Led by Justice Scalia, the Court invalidated that city's hate crimes ordinance, giving great weight to speech rights but scarcely any to the harm suffered by

29. Abrams v. United States, 250 U.S. 616, 628 (1919) (Holmes, J., dissenting). In his now famous argument, Justice Holmes wrote,

[W] hen men have realized that time has upset many fighting faiths, they may come to belicve even more than they believe the very foundations of their own conduct that the ultimate good desired is better reached by frce trade in ideas-that the best test of truth is the power of the thought to get itself accepted in the competition of the market, and that truth is the only ground upon which their wishes safely can be carried out.

Id. at 630 .

The Free Speech Clause of the First Amendment provides, in relevant part: "Congress shall make no law . . . abridging the freedom of specch ...." U.S. CoNST. amend. I.

30. Henry Louis Gates, Jr., Let Them Talk: Why Civil Liberties Pose No Threat to Civil Rights, New Republic, Sept. 20, 1993, at 37.

31. See infra Part II.B.

32. See infra notes $109-11$ and accompanying text.

33. 112 S. Ct. 2538 (1992).

34. Id. 
hate speech victims. The facts of R.A.V. resemble countless other racist incidents. Before dawn on June 21, 1990, Robert A. Viktora and several other teenagers assembled a crude cross by taping together broken chair legs. ${ }^{35}$ They then set the cross ablaze in the yard of an African American family living across the street from Viktora, who was subsequently charged under St. Paul's Bias-Motivated Crime Ordinance. ${ }^{36}$ Noting that Viktora might have been charged under any number of laws, ${ }^{37}$ the Court unanimously struck down the St. Paul ordinance, but for sharply divergent reasons.

Writing for the five-member majority, Justice Scalia accepted the Minnesota Supreme Court's construction of the ordinance, whicl limited the ordinance's reach only to "fighting words."38 Even this, however, was imsufficiently narrow to save the ordinance. Justice Scalia reasoned that neither fighting words nor any of the few other traditional limitations to free speecli ${ }^{39}$ were "categories of speech entirely invisible to the Constitution, so that they inay be made the vehicles for content discrimination unrelated to their distinctively proscribable content." 30 For example, the government inay proscribe all libel, but not only libel that is critical of the government. Similarly, a city may prohibit all fighting words, but not only those fighting words whose content or viewpoint it disagrees with, as St. Paul had done. Scalia wrote that "[ $t$ ]he government may not regulate [modes of speech] based on hostility-or favoritism-towards the underlying inessage expressed," "41 even when that message is one of racial hatred.

In concluding his opinion, Justice Scalia added, "Let there be no mistake about our belief that burning a cross in soineone's front yard is reprehensible."42 Charles Lawrence called this gesture "an obligatory genuflection to decency." In focusing exclusively on the alleged constitutional injury to R.A.V., Lawrence argues, the Court gave little thought to

35. Id. at 2541 .

36. Id. The ordinance provides:

Whoever places on public or private property a symbol, object, appellation, characterization or graffiti, including, but not limited to, a burning cross or Nazi swastika, which one knows or has reasonable grounds to know arouses anger, alarm or resentment in others on the basis or race, color, creed, religion or gender commits disorderly conduct and shall be guilty of a misdemeanor.

Id. (quoting Sr. PAUL, MinN. LeGis. CODE § 292.02 (1990)).

37. Id.

38. Id. On "fighting words," sce Chaplinsky v. New Hampshire, 315 U.S. 568, 572 (1942) (holding that fighting words, "those which by their very utterance inflict injury or tend to incite an immediate breach of the peace," do not merit First Amendment protection).

39. In addition to Chaplinsky, the Court cited Roth v. United States, 354 U.S. 476 (1957) (obscenity), and Beauharnais v. Illinois, 343 U.S. 250 (1952) (defamation). R.A.V., 112 S. Ct. at 2543. See also infra text accompanying notes 79-81.

40. R.A.V., 112 S. Ct. at 2543.

4I. Id. at 2545 .

42. Id. at 2550 .

43. Lawrence, Crossburning, supra note 8, at 791. 
the family harmed by R.A.V.'s free speech. ${ }^{44}$ Russ and Laura Jones had moved with their children to East St. Paul in order to escape the drugs and violence of the inner city. ${ }^{45}$ What of "this black family's right to live where they pleased, or their right to associate with their neighbors"? asked Lawrence. ${ }^{46}$ What of their pain and fear? Surely these harms were worthy of the Court's consideration even if they did not rise to the level of constitutional injuries.

\section{B. The Victims' Due}

Critical race theorists like Lawrence have long argued from the perspective of the victim. How can we diaguose the disease and prescribe a cure without listening to the patient? Mari Matsuda rejects First Amendment absolutism and gives voice to victims' stories of the effects of racist speech. ${ }^{47}$ Matsuda grounds leer "outsider jurisprudence" in the social reality and experience of people of color. ${ }^{48}$ She combines an emphasis on effects with a search for progressive legal tools, "defying the habit of neutral principles to entrench existing power."49

Matsuda devotes Part III of ler seminal article to documenting racist incidents and the damage they cause. ${ }^{50}$ She writes,

Racist hate messages, threats, slurs, epithets, and disparagement all hit the gut of those in the target group. The spoken message of hatred and inferiority is conveyed on the street, in schoolyards, in popular culture and in the propaganda of hate widely distributed in this country. Our college campuses have seen an epidemic of racist mcidents .... ${ }^{51}$

Among the effects of racial hate speech are fear; mghtnares; post-traumatic stress disorder; hypertension; psycliosis; loss of personal freedoin, einployment, education, self-esteem, and personal security; even suicide. ${ }^{52}$ Patricia Williams calls the phenomenon "spirit murder." 53

Richard Delgado also argues froin the perspective of the victim. He writes that racial slurs, "relying as they do on the unalterable fact of the victim's race and on the history of slavery and race discrimination in this

44. Id. at 790. In fact, the opinion does not even mention their name.

45. Akhil R. Amar, The Case of the Missing Amendments: R.A.V. v. City of St. Paul, 106 HARv. L. Rev. 124, 161 n.188 (1992) (citing Don Terry, Rights Advocates Uncertain About Ruling's Impact, N.Y. Times, June 23, 1992, at A16).

46. Lawrence, Crossburning, supra note 8, at 788 (footnote omitted).

47. Matsuda, supra note 8, at 2321.

48. Id. at 2324-25.

49. Id. at 2325.

50. Id. at 2326.

51. Id. at 2332 (footnote omitted).

52. Id. at $2336-37$.

53. Id. at 2337 (quoting Patricia Williams, Spirit-Murdering the Messenger: The Discourse of Fingerpointing as the Law's Response to Racism, 42 U. MiAM L. Rev. 127, 129 (1987)). 
country, have an even greater potential for harm than other insults."54 Delgado adds that racial insults have a disproportionate impact on children, who are only beginning to form their thoughts and feelings about race, and thus are inore vubierable to the attacks. ${ }^{s s}$ Though no longer children, college students also may lack the confidence and self-esteein necessary to shield thein froin racist speech. They too may "coine to question their coinpetence, intelligence, and worth," 56 if they do not already do so. "To be hated, despised, and alone is the ultinate fear of all human beings," observes Matsuda. ${ }^{57}$ "The aloneness coines not only from the hate message itself, but also froin the government response of tolerance." 58 Moreover, "[t]olerance of hate speech is not tolerance borne by the commumity at large. Rather it is a psychic tax imposed on those least able to pay." 59

Like all hate speech victims, college students who are members of target groups suffer injury to their dignity and self-regard, often experiencing feelings of humiliation, isolation, and self-liatred. ${ }^{60}$ They are especially vulnerable since they inay be far from liome and in an environment much different from the inner cities, Asiatowns, and barrios where they nnay have grown up. Many students are forging an identity, developing new ties, and redefining their relationship with the world around thein. ${ }^{61}$ When minority students are faced with the shock and stress of hate speech-whether directed at thein or at others of their race, perhaps friends or relativespassivity, reticence, and self-innposed anonymity are too often the result. Hate speech silences both physically, througl intimidation and threats of further harassinent or actual violence, and spiritually, by demoralizing its victims.

Charles Lawrence has perhaps best described the silencing effects of hate speech. In arguing that face-to-face racial insults- "fighting words"can be constitutionally penalized, Lawrence notes that being called a "nigger" is like being slapped in the face. ${ }^{62}$ The imjury is instantaneous, allowing no time for either reflection on the idea conveyed or responsive

54. Delgado, Words That Wound, supra note 8, at 143.

55. Id. at $146-47$.

56. Id. at 146.

57. Matsuda, supra note 8, at 2338.

58. Id.

59. Id. at 2323.

60. Delgado, Words That Wound, supra note 8, at 135-37; see also Richard Delgado \& David H. Yun, Pressure Valves and Bloodied Chickens: An Analysis of Paternalistic Objections to Hate Speech Regulation, 82 Calfr. L. Rev. 871, 888 n.112 (1994) (citing Gordon W. Altport, The Nature of Presdice 142-61 (1954); Mary Ellen Goodman, Race Awareness nn Young Children 55-58, 60 (rev. ed. 1964); George E. Simpson \& J. Mitton Yinger, Racial and Cultural Minorties: AN ANALYsis of Presudice AND Discrmanation 157-58 (4th ed. 1972); Ruben Martinez \& Richard Dukes, Ethnic and Gender Differences in Self-Esteem, 22 YoutH \& Soc'Y 318, 332 (1991)).

61. See Matsuda, supra note 8, at 2370-71 \& n.249 (suggesting that "[a] negative environmental response during this period of experimentation could mar for life an individual's ability to remain open, creative, and risk-taking").

62. Lawrence, If He Hollers, supra note 8, at 452. 
speech. ${ }^{63}$ He writes, "Assaultive racist speech functions as a preemptive strike. The racial invective is experienced as a blow, not a proffered idea, and once the blow is struck, it is unlikely that dialogue will follow." ${ }^{\prime 64}$

Lawrence argues that woinen and ininorities often find theinselves speechless in the face of discriminatory insults for a number of reasons. First, the "visceral emotional response to personal attack precludes speech. . . . Fear, rage, shock, and flight all interefere with any reasoned response. . . . Many victims do not find words of response until well after the assault when the cowardly assaulter has departed."65 Second, speech is often an inadequate response given the preeinptive nature of racial insults. "When one is personally attacked with words that denote one's subhuman status and untouchability, there is little (if anything) that can be said to redress either the einotional or reputational injury."66 Third, "[t]he fighting words doctrine presupposes an encounter between two persons of relatively equal power who have been acculturated to respond to face-to-face insults with violence." 67 In inany cases, however, a minority student will be confronted by inore than one attacker, and, by dint of sheer numbers, silence is the safer option. 68 Lastly, Lawrence reminds us of the effects of "pervasive racial and sexual violence and coercion on individual members of subordimated groups who inust learn the survival techniques of suppressing and disguising rage and anger at an early age." 69

Not only students, but professors, feel the effects of racisin and racist speech. In the inaugural issue of the Asian Law Journal, Robert Chang, an Asian American law professor, wrote of the need for an Asian American Legal Scholarship. He began his article thus:

Of the different voices in which I speak, I have been most comfortable with the one called silence. Silence allowed ine to escape notice when I was a child. I could become invisible, and hence safe.

Yet now I find myself leaving the safety of my silence. I wonder if this is wise. ${ }^{70}$

Unfortunately, both critics of regulation and mainstream society question the urgency of the hate speech problein. ${ }^{71}$ Law review articles supporting hate speech regulations are typically written only by inembers of groups
63. Id.
64. Id.
65. Id. at $452-53$.
66. Id. at 453 .
67. Id. at $453-54$
68. Id. at 454.
69. Id. at 454-55. But see Post, supra note 7, at 310 (suggesting that, even if minorities are systematically and preemptively silenced, this may be the result of raeism itself rather than racist
70. Robert S. Chang, Toward an Asian American Legal Scholarship: Critical Race Theory, Post- Structuralism, and Narrative Space, 81 CALIF. L. Rev. 1241, 1244 (1993), 1 ASIAN L.J. 1, 4 (1994).
71. See Matsuda, supra note 8, at 2326-27. speech). 
who have been victims of hate speech. ${ }^{72}$ Outside of academia, stories about racially motivated attacks and vandahism are reported regularly in the ethnic press but only occasionally in the popular media. This may give inany people the impression that such episodes are sporadic. ${ }^{73}$ In contrast, "[f]roin the victim's perspective, all of [the] implements [of racism] inflict wounds, wounds that are neither randoin nor isolated. . . Less egregious forms of racism [such as hate speech] degenerate easily into more serious forms." But the arbiters of the law are seldoin meinbers of target groups, and they remain unpersuaded. Like the R.A.V. Court, they continue to discount the severity of the harm suffered by hate speech victims.

\section{R.A.V.: The Other Half of the Story?}

Some ineinbers of the judiciary have in fact taken the victim's perspective into account. Although four nnembers of the R.A.V. Court concurred in the result, they did so with much inore sympathy for the City's purpose and for people of color than did the inajority. Justice White, joined by Justices Blackmun, O'Connor, and Stevens, wrote that St. Paul's selective regulation of fighting words reflected the City's judgment that "harms based on race, color, creed, religion, or gender are more pressing public concerns than the harms caused by other fighting words. In light of our Nation's long and painful experience with discrimination, this determination is plainly reasonable."75 Justice Blackmun, writing separately, added:

I see no First Amendment values that are compromised by a law that prohibits hoodlums from driving minorities out of their homes by burning crosses on their lawns, but I see great harm in preventing the people of Saint Paul from specifically punishing the race-based fighting words that so prejudice their community. ${ }^{76}$

Justice Stevens was even more explicit in his approval of the ordinance's goals:

72. Id. at 2326 n.36 (citing Kammy Au, Comment, Freedom from Fear, 15 Lncoln L. REv. 45 (1984) (arguing for revival of judicial recognition of group defamation law in response to increased antiAsian violence and propaganda); Delgado, Words That Wound, supra note 8; Thomas D. Jones, Article 4 of the International Convention on the Elimination of All Forms of Racial Discrimination and the First Amendment, 23 How. L.J. 429 (1980) (advocating a legal response to racist speech); David Kretzmer, Freedom of Speech and Racism, 8 CARDozo L. REv. 445 (1987) (concluding that hate speech restrictions do not necessarily impinge upon freedom of expression, and that their desirability depends upon existing social conditions)).

73. Matsuda, supra note 8 , at $2330-31$.

74. Id. at 2335.

75. R.A.V. v. City of St. Paul, 112 S. Ct. 2538, 2556 (1992) (White, J., concurring). Although Justice White acknowledged St. Paul's compelling interest in discouraging hate speech, he agreed that the city's ordinance was overbroad in its application of the fighting words exception even to speech that caused merely "anger, alarm or resentment." Id. at 2559. "The mere fact that expressive activity causes hurt feelings, offense, or resentment does not render the expression unprotected." Id.

76. Id. at 2561 (Blackmun, J., concurring). Nevertheless, like Justice White, Justice Blackmun concluded that the ordinance was overbroad in its use of the fighting words doctrine. Id. 
Just as Congress may determine that threats against the President entail more severe consequences than other threats, so St. Paul's City Council may determine that threats based on the target's race, religion, or gender cause more severe harm to both the target and to society than other threats. This latter judgment- that harms causcd by racial, rehgious, and gender-based invective are qualitatively different from that caused by other fighting words-seems to me eminently reasonable and realistic. ${ }^{77}$

In their recogmition of the unique trauma caused by hate specch, these four justices echo Lawrence, Matsuda, and Delgado. They rccogmize that, at least with regard to fighting words, this harm constitutes sufficient justification for hate speech regulation-that devastating injury is sufficient justification for an exception to freedom of speech. ${ }^{78}$ This recognition is reflected in the Court's finding in Chaplinsky v. New Hampshire ${ }^{79}$ that certain narrow limitations to freedom of speech were constitutional, imcluding the prohibition of "the lewd and obscene, the profane, the libelous, and the insulting or 'fighting' words."80 Such expressions possess only "slight social value as a step to truth," which benefit was "clearly outweighed by the social interest in order and morality." 81 Thus, the Court found that the harm caused by these categories of expression justified their proscription.

The harm caused by hate speech has many of the characteristics that the Court identifies as reasons for limiting freedom of speech. What is more debilitating than being called, along with all others of one's race, a chink, a nigger, a gook, or a spic? All at once, these words are obscene, profane, libelous, and imsulting. Moreover, they have only negligible "social value," if any. As one commentator notes, "[T] he civil libertarian cannot in his or her heart truly imagine that the speech of the Ku Klux Klan or the Nazis can have any redeeming social value." 82

This calculus has been made before, however, and skeptics remain unconvinced that the harm caused by hate speech outweighs its inherent value as expression. The degree of harm suffered by hate speech victims suggests a solution. In another area of law, courts have made an exception to a constitutional principle in order to remedy past wrongs. The widespread judicial acceptance of affirmative action programs confirms that redressing racial mjustice is so compelling a purpose that it justifies race-

77. Id. at 2565 (Stevens, J., concurring). Justice Stevens also agreed, however, that the ordinance's overbreadth was fatal. Id. at 2571.

78. Although campus hate speech codes constitute an exception to freedom of speech in the narrow sense that they limit speech by some students, they are cntirely consistcnt with freedom of speech in a larger sense, since they increase speech opportunitics for students of color. Thus, I use the word "exception" here only in the narrow sense.

79. 315 U.S. 568 (1942).

80. Id. at 572 .

81. Id.

82. Rodney A. Smolla, Rethinking First Amendment Assumptions About Racist and Sexist Speech, 47 Wash. \& LeE L. Rev. 171, 175 (1990). 
based preferences that would otherwise be unconstitutional. Parts III and IV argue that people of color have suffered past and present discrimination in the exercise of their speech rights, just as they have endured discrimination in employment, education, housing, and voting rights. So long as hate speech regulations are rooted in the racial injustice that has so long silenced people of color, they are no more radical and no inore unconstitutional than established affirmative action programs.

\section{III}

\section{Affirmative Action in Fammiar Contexts}

With its landmark decision in Regents of the University of California v. Bakke, ${ }^{83}$ the Supreme Court embarked on a long, often difficult course in analyzing affirmative action prograins. Bakke struck down the special admissions plan of the Umiversity of California at Davis inedical school but left the door open for plans that respect the individual rights guaranteed by the Fourteenth Amendment. ${ }^{84}$ Regrettably, the Bakke plurality failed to clarify precisely what constitutes an acceptable preference prograin. This Part provides a short summary of affirmative action law as shaped by the Court in Bakke and the cases that followed.

\section{A. The Seminal Case-Strict Scrutiny Required}

Writing the deciding opinion in Bakke, Justice Powell found, first, that affirmative action plans would be subject to the same strict scrutiny ${ }^{85}$ applied to other race-based preference programs, even though the former benefitted the same minority groups historically disadvantaged by the latter. ${ }^{86}$ Justice Powell emphasized that the Fourteenth Amendment's "guarantee of equal protection cannot mean one thing when applied to one individual and soinething else when applied to a person of another color. If both are not accorded the same protection, then it is not equal.".87

83. 438 U.S. 265 (1978).

84. Id. at 320 (opinion of Powell, J.).

85. The strict scrutiny standard is more rigorous than both the intermediate scrutiny and rational basis standards. The strict scrutiny test is set forth infra text accompanying note 91 . On the intermediate scrutiny and rational basis rules, see infra note 101 and accompanying text.

86. Bakke, 438 U.S. at 290-305 (opinion of Powell, J.).

87. Id. at 289-90 (opinion of Powell, J.). Justice Powell explicitly rejected an argument based on the much remarked footnote from United States v. Carolene Prods. Co., 304 U.S. 144 (1938), in which an earlier Court suggested an nicrease in judicial protection of minorities. Bakke, 438 U.S. at 290-91 (opinion of Powell, J.). Carolene Products involved a challenge to federal legislation prohibiting the shipment in interstate commerce of filled milk. In its discussion of the deference usually accorded to the legislature, the Carolene Products Court observed that the presumption of constitutiouality may narrow "when legislation appears on its face to be within a specific prohibition of the Constitution." 304 U.S. at 152 n.4. It added:

Nor need we enquire whether similar considerations enter into the review of statutes directed at particular religious, or national, or racial minorities: whether prejudice against discrete and insular minorities may be a special condition, which tends seriously to curtail the 
In particular, Justice Powell identified three serious problems of justice linked to the idea of preference that argue for a more rigorous standard of evaluation. ${ }^{88}$ First, it will not always be clear that a preference is bemgn. Second, preferential programs may reinforce the stereotype that minorities are unable to succeed without special protection, and perpetuating this misconception harms minority groups. Third, it is inequitable to force innocent persons to shoulder the burden of redressing harms they did not cause. ${ }^{89}$ Additionally, Justice Powell articulated a fourth concern: previously approved preferential classifications involved judicial, admimistrative, or legislative findings of past discrimination. Such findings confirmed the existence of a wrong in need of a remedy, as well as providing a means of measuring - and limiting - the scope of the remedy. ${ }^{90}$ Justice Powell's four major concerns have recurred in nearly every affirmative action case since Bakke, as they will in this Comment.

Having settled on the standard to be used in evaluating the Davis program, Justice Powell found that the one element of the strict scrutiny test was satisfied, but not the other. In order to pass strict scrutimy, a suspect classification must be narrowly tailored to serve a compelling governmental purpose. ${ }^{91}$

The Davis medical school identified four purposes for its special admissions program: (1) imcreasing the number of traditionally disfavored mimorities in medicine; (2) countering the effects of societal discrimmation; (3) increasing the number of physicians who practice in underserved communities; and (4) obtaining the educational benefits of an ethnically diverse student body. ${ }^{92}$ Althougli Justice Powell rejected the first three goals, he agreed that the fourth was sufficiently compelling to justify a race-based preference..$^{93}$

Nevertheless, the Davis special admissions program failed because it was not narrowly tailored; that is, the program was not necessary to ensure a diverse student body. ${ }^{94}$ Justice Powell argued that the state's interest was broader than simple ethnic diversity, "im which a specified percentage of the student body is im effect guaranteed to be members of selected ethnic

operation of those political processes ordinarily to be relied upon to proteet minorities, and

which may call for a correspondingly more searching judicial inquiry.

Id. (citations omitted). However, Justice Powell contended in Bakke that "[i]t [was] far too late to argue that the guarantee of equal protection to all persons permits the recognition of special wards entitled to a degree of protection greater than that accorded others." 438 U.S. at 295 (opinion of Powell, J.).

88. Bakke, 438 U.S. at 298 (opinion of Powell, J.).

89. Id.

90. Id. at 300-01, 307-09 (opinion of Powell, J.).

91. Wygant v. Jackson Bd. of Educ., 476 U.S. 267, 274 (1986); Palmore v. Sidoti, 466 U.S. 429, $432-33$ (1984); Bakke, 438 U.S. at 305 (opinion of Powell, J.) (stating a substantially similar formulation in which the classification must be " "necessary ... to the accomplishment" " of a "substantial" purpose) (quoting In re Griffiths, 413 U.S. 717, 721-22 (1973)) (footnote omitted).

92. Bakke, 438 U.S. at 306 (opinion of Powell, J.).

93. Id. at 307-12 (opinion of Powell, J.).

94. Id. at 315-16 (opinion of Powell, J.). 
groups."95 Instead, race or ethnicity is only a single though important coinponent of the "far broader array of qualifications and characteristics" constituting the diversity that is a compelling state interest. ${ }^{96}$ Although race and ethnicity may be considered a "plus" in a particular applicant's file, they cannot insulate the applicant froin comparison with all other applicants. ${ }^{97}$ To be valid, an admissions program inust treat eacli candidate "as an individual." 98

\section{B. The Cases That Followed-Strict Scrutiny Interpreted}

In the cases following Bakke, the Court has clarified and expanded its analysis. A inajority of the Court adopted the strict scrutiny standard for the first time in City of Richmond v. J.A. Croson Co. ${ }^{99}$ Echoing Justice Powell's arguments in Bakke, Justice O'Connor rejected arguments for an intermediate level of scrutiny, ${ }^{100}$ which would have required only that affirmative action programs be "substantially related" to an "important" governmental purpose. ${ }^{101}$

Among the factors weighing against a more relaxed standard were the inpossibility of objectively determining what constitutes a bemign use of race and the danger of stigmatic harm to the minority group, ${ }^{102}$ both factors that were cited in Bakke. ${ }^{103}$ Justice O'Connor observed that the dissent's "watered-down version of equal protection review," which incorporated intermediate scrutiny, would ensure that race would always be at issue in American life and in governmental decisionmaking. ${ }^{104}$ Justice Marshall responded:

In concluding that remedial classifications warrant no different standard of review under the Constitution than the most brutal and repugnant forms of state-sponsored racisin, a majority of this Court

95. Id. at $\mathbf{3 1 5}$ (opinion of Powell, J.).

96. Id.

97. Id. at 317 (opinion of Powell, J.).

98. Id. at 318 (opinion of Powell, J.).

99. 488 U.S. 469 (1989) (invalidating a minority set-aside program that required prime contractors receiving city construction contracts to subcontract at least $30 \%$ of the dollar value of the contract to one or more Minority Business Enterprises).

100. Id. at 493-98 (opinion of O'Connor, J.).

101. For formulations of the intermediate scrutiny standard, see Metro Broadeasting, Inc. v. FCC, 497 U.S. 547, 564-65 (1990); Croson, 488 U.S. at 535 (Marshall, J., dissenting); Fullilove v. Klutznick, 448 U.S. 448, 519 (1980) (Marshall, J., concurring); Bakke, 438 U.S. at 361 (Brennan, White, Marshall, \& Blackmun, JJ., concurring in part and dissenting in part). Metro Broadcasting and Fullilove are discussed infra in Part III.C.

Even more permissive than strict scrutiny and intermediate scrutiny is the rational basis test, which is applied when a classification does not implicate fundamental personal rights and is not drawn upon inherently suspect distinctions. City of New Orleans v. Dukes, 427 U.S. 297, 303 (1976). Such a classification need only be "rationally related" to a "legitimate" state interest. Id.

102. Croson, 488 U.S. at 493-94 (opinion of O'Connor, J.).

103. Bakke, 438 U.S. at 298 (opinion of Powell, J.).

104. Croson, 488 U.S. at 495 (opinion of O'Counor, J.). 
signals that it regards racial discrimination as largely a phenomenon of the past, and that government bodies need no longer preoccupy themselves with rectifying racial injustice. I, however, do not believe this Nation is anywhere close to eradicating racial discrimination or its vestiges. ${ }^{105}$

Except in a few instances, ${ }^{106}$ however, the Court has stood firm in its logic. Having established the applicability of the strict scrutiny standard, the Court moved to an evaluation of content. In assessing what constitutes a compelling purpose, Justice Powell reiterated in Wygant v. Jackson Board of Education ${ }^{107}$ that societal discrimination alone is too amorphous to justify a racial classification: "In the absence of particularized findings, a court could uphold reinedies that are ageless in their reach into the past, and timeless in their ability to affect the future."108 Wygant emphasized that there must be compelhing evidence to support a claim of past discrimination. ${ }^{109}$ Three years later, the Croson Court stressed that a generalized assertion of past discrimination $\mathrm{m}$ an entire imdustry is insufficient to justify a race-based preference because it is too vague to provide a logical stopping point for the reinedy. ${ }^{110}$

Nonetheless, according to Justice O'Connor's influential Wygant concurrence, "a contemporaneous or antecedent finding of past discrimination by a court or other competent body is not a constitutional prerequisite to a public employer's voluntary agreement to an affirmative action plan."111 Thus, it seeins that sufficient evidence-but not a formal finding —of past discrimination is necessary to establish a compelling governmental purpose for a remedial racial classification.

The second prong of the strict scrutiny standard deinands that a racial classification be narrowly tailored. ${ }^{112}$ Motivated by concern for the inajority group, this requirement will invalidate the use of a racial classification if it imposes an undue burden on innocent parties. In Wygant, Justice Powell acknowledged that the innocent may be asked to bear soine of the burden of a remedy, "[a]s part of this Nation's dedication to eradicating racial discrimination."113 However, Justice Powell held that the preferential layoff scheme at issue placed an unacceptable hardship on teachers who were laid off even though they were semior to some African American teachers who were not laid off. ${ }^{114}$ Justice Powell contrasted this burden to the more dif-

105. Id. at 552 (Marshall, J., dissenting).

106. See infra Part III.C.

107. 476 U.S. 267 (1986) (invalidating a layoff policy that preserved the jobs of African American teaclers, though they were less senior than some white teachers who were laid off).

108. Id. at 276 (opinion of Powell, J.).

109. Id. at 277 (opinion of Powell, J.).

110. Croson, 488 U.S. at 498.

111. Wygant, 476 U.S. at $289^{\circ}\left(O^{\prime}\right.$ Connor, J., concurring in part and concurring in the judgment).

112. Id. at 280 (opinion of Powell, J.).

113. Id. at 280-81 (opinion of Powell, J.).

114. Id. at 282-83 (opinion of Powell, J.). 
fuse burden imposed by preferential hiring programs, finding that "[d]enial of a future employment opportunity is not as intrusive as loss of an existing job."115

In his closing sentences, Justice Powell suggested the adoption of hiring goals as an alternative, ${ }^{116}$ seemingly ignoring both reality and experience. As Justice Marshall observed in his dissent, "[a]s a matter of logic as well as fact, a hiring policy achieves no purpose at all if it is eviscerated by layoffs." 117

Justice Marshall argued that the layoff program was narrowly tailored because it allocated the burden proportionately between the two racial groups involved, because it preserved the hierarchy of seniority to some extent, and because it did not use layoff protection to increase minority representation, but only to preserve increases achieved through less drastic means. ${ }^{118}$ Moreover, the layoff program operated within a narrow tine frame since it would terminate when remedial measures were no longer required. ${ }^{119}$ Perhaps inost miportant, the program inodified contractual provisions that did not "carry any connotation of merit or achievement; it [did] not interfere with the 'cherished American ethic' of '[ $\mathrm{f}] \mathrm{airness}$ in individual competition." "120

In considering the narrow tailoring requirement in the context of a minority set-aside program, the Croson Court, first, called for consideration of race-neutral means to increase minority business participation and, second, argued against any assumption that minorities would choose a particular trade "in lockstep proportion to their representation in the local population." 121 Justice O'Connor, who wrote for the Croson majority, had earlier inade a similar argument in her concurring opinion in Wygant, where she agreed that the disputed layoff program was not narrowly tailored, since there was no relation between the hiring goals furthered by the program and the asserted remedial purpose. ${ }^{122}$ According to Justice O'Connor, such a hiring goal should have been linked to the percentage of qualified minority teachers, not the percentage of minority students in the school district. The disparity between the percentages of minority teachers and minority students was considered irrelevant for the purposes of the analysis. ${ }^{123}$

Lastly, in Croson as in Bakke, the Court underscored the need in a narrow tailoring analysis to treat all parties as individuals, "rather than mak-

115. Id.

116. Id. at 283-84 (opinion of Powell, J.).

117. Id. at 307 (Marshall, J., dissenting).

118. Id. at 309 (Marshall, J., dissenting).

119. Id.

120. Id. (quoting Bakke, 438 U.S. at 319 ) (second alteration in original).

121. City of Richmond v. J.A. Croson Co., 488 U.S. 469, 507 (1989).

122. Wygant v. Jackson Bd. of Educ., 476 U.S. 267, 294 (O'Connor, J., concurring in part and concurring in the judgment).

123. Id. 
ing the color of an apphicant's skin the sole relevant consideration."124 In particular, the Court noted the importance of procedures to consider whether any particular party had in fact suffered from the effects of past discrimination. ${ }^{125}$

\section{The Exceptions-Intermediate Scrutiny Approved}

The Court's concern for treating individuals as individuals underlies its msistence on the strict scrutiny test. Nonetheless, the Court has approved a less rigorous standard of review where the disputed racial classification was implemented by Congress. ${ }^{126}$ In Metro Broadcasting, Inc. v. Federal Communications Commission, ${ }^{127}$ the Court adopted an intermediate scrutiny test in approving FCC minority preference policies. ${ }^{128}$ The two policies involved awarded an enhancement for minority ownership in applications for new broadcasting licenses and made a limited number of radio and television stations available only to minority-controlled firms in "distress" sales. 129

In its endorsement of intermediate scrutiny, the Court gave "overriding significance" to the role played by Congress and the deference that was appropriate "in light of Congress' institutional competence as the National Legislature."130 The Court concluded that

benign race-conscious neasures mandated by Congress-even if those measures are not "reinedial" in the sense of being designed to compensate victims of past governmental or societal discrimination-are constitutionally permissible to the extent that they serve important governmental objectives within the power of Congress and are substantially related to achievenient of those objectives. ${ }^{131}$

Furthermore, Justice Brennan, writing for the majority, cited with approval Justice O'Connor's statements in Croson that " Congress may identify and redress the effects of society-wide discrinination" "132 and "need not make specific findings of discrimination to engage $i \mathrm{~m}$ race-conscious relief." "133

In validating intermediate scrutiny of Congressional action, Justice Brennan relied heavily on Fullilove v. Klutznick, ${ }^{134}$ where the Court upheld

124. Croson, 488 U.S. at 508.

125. Id.

126. For a discussion of the Court's upcoming decision in Adarand Constructors, Inc. v. Pena, 16 F.3d 1537 (10th Cir. 1994), cert. granted, 115 S. Ct. 41 (1994) (No. 93-1841) (reconsidering the level of scrutiny to be applied to federal minority set-aside programs), see supra text accompanying note 19.

127. 497 U.S. 547 (1990).

128. Id. at 564-65.

129. Id. at 552.

130. Id. at 563 (citing Fullilove v. Klutznik, 448 U.S. 448 (1980) (opinion of Burger, C.J.)).

131. Id. at 564-65 (footnote omitted).

132. Id. at 565 (quoting Croson, 488 U.S. at 490 ).

133. Id. (quoting Croson, 488 U.S. at 489 ).

134. 448 U.S. 448 (1980). 
a ten-percent set-aside for minority business enterprises in federally funded public works projects. In his opinion in Fullilove, Chief Justice Burger noted that the set-aside had been mandated by Congress, and underscored the great weight generally accorded to the decisions of Congress as a coequal branch. ${ }^{135}$

Chief Justice Burger's Fullilove opinion adopted neither strict nor intermediate scrutiny, but an analysis of (1) whether the objectives of the set-aside prograin were within the power of Congress, and (2) whether the limited use of racial and ethnic criteria was a constitutionally permissible means for achieving those objectives. ${ }^{136}$ In Metro Broadcasting, the Court emphasized that a inajority of the Fullilove Court did not apply strict scrutiny. ${ }^{137}$ However, Justice O'Connor argued in her dissent that six meinbers of the Fullilove Court-a majority-rejected intermediate scrutiny in favor of a inore stringent requirement. ${ }^{138}$

It is not entirely clear, therefore, if and when intermediate scrutiny will be applied to even those racial classifications implemented by Congress. ${ }^{139}$ However, Part IV will demonstrate that campus hate speech regulations should survive even the strict scrutiny detailed in Bakke and its progeny.

\section{IV}

\section{Affirmative Action IN the Context of SpeEch Rights}

Supporters of the First Amendment have long inaintained that the importance of speech rights precludes their preemption. ${ }^{140}$ In the hate speech context, however, this argument cuts both ways. How should the law respond when freedom of speech amplifies the shrill voice of racisin while silencing its victims? This Part argues that people of color, especially students, ${ }^{141}$ have too long been quieted by expressions of bigotry and hate. In the allocation of speech rights, no less than in the distribution of public funds, educational resources, and employment opportunities, minorities deserve full and equal access. As in those other arenas, equality will not be

135. Id. at 472 (opinion of Burger, C.J.).

136. Id. at 473 (opinion of Burger, C.J.).

137. Metro Broadcasting, 497 U.S. at 564.

138. Id. at 608 (O'Connor, J., dissenting).

139. Furthermore, recent personnel changes on the Court have given it a decidedly more conservative cast. Of the five justices in the 1990 Metro Broadcasting majority, Justices Brennan, Marshall, White, and Blackmnn have since been replaced by Justices Souter, Thomas, Ginsburg, and Breyer.

The Court's impending decision in Adarand Constructors, Inc. v. Pena, 16 F.3d 1537 (10th Cir. 1994), cert. granted, 115 S. Ct. 41 (1994) (No. 93-1841), may well determine the question. See supra note 19.

140. See, e.g., Terminiello v. Chicago, 337 U.S. 1, 4 (1949).

141. For convenience, I refer to both victims and perpetrators of hate speech as students. I do not intend, however, that administrators, faculty, staff, and other campus personnel should be exempted from the requirements or denied the protections of hate speech regulations. 
possible without temporary mequality im the form of affirmative action or, what is the same in the First Amendment context, hate speech regulations.

Part IV.A addresses hate speech regulations under the intermediate scrutiny standard, noting that some of the traditional concerns with affirmative actions programs do not apply in the speech context. Part IV.B analyzes hate speech regulations under the strict scrutiny test, with attention to First Amendment issues.

At the outset, I note that a hate speech code grounded in an affirmative action rationale necessitates asymmetrical application. Because whites have not been systematically silenced by racist speech, ${ }^{142}$ protecting them from such speech is not logically justified under affirmative action law. Hence, whites would be prohibited from using hate speech against minorities, but minorities would not be prohibited from using such speech against whites. ${ }^{143}$

This result seems anomalous at first glance-contrary to our ultimate goal of mutual respect and understanding among racial and ethnic groups. However, an asymmetrical hate speech code has several advantages. First, it would circumscribe less speech than its symmetrical counterpart, since only racist speech against minorities would be restricted. Second, an asymmetrical rule would deal adequately with the problem of racist speech by one minority against another, since the permissibility of racist speech would depend on the race or ethnicity of the victim, not of the perpetrator. Finally, asymmetrical hate speech regulations reflect the umque nature of the harm suffered by minority victims of racist speech.

Grounding hate speech codes im an equal protection rationale seems to call for a symmetrical scheine prohibiting all racist speech, whether directed at whites or students of color. Some would argue that advancing the speech rights of minorities does not require us to himit the speech rights of whites. There may be a limitless quantity of speech rights. In other areas-college admissions and job hiring, for example-advancing minorities necessarily disadvantages whites because there are limited numbers of admission slots or job openings. The same is not true when it comes to the allocation of speech rights - that particular "pie". seems unlimited.

However, if an expansion of speecl rights occurs only with a corresponding contraction, then speech rights are not im fact unlimited in quantity. Protecting whites froin hate speech curtails the speech rights of those who target them, just as protecting minorities curtails speech rights. In the case of minorities, this cost is justified as a remedy for years of speech discrimination. No similar justification exists for protecting whites, how-

142. Individual whites may be silenced in specific incidents of racist spcech against them, but the aggregate effect of hate speech against the majority pales in comparison to the effect of hate spcech against minorities.

143. See also Amar, supra note 45 , at $159-60$ (discussing the benefits of an asymmetrical hate speech regulation grounded in the Thirteenth Amendment). 
ever. Although equal protection theory explains special protection for minorities' speech rights, it does not justify special protection for the speech rights of the majority. Hate speech regulations are no more drastic than other forms of affirmative action, under which minorities receive preferences simply because of the color of their skin. This is the cost of true equality and true freedom of speech.

\section{A. Hate Speech Regulations Under an Intermediate Scrutiny Standard}

\section{Congressional Enactment of Hate Speech Regulations.}

Were Congress to mandate hate speech regulations on college campuses, the Fullilove and Metro Broadcasting line of argument might well permit application of an intermediate scrutiny standard to such legislation rather than the usual strict scrutiny. ${ }^{144}$ Like the policies at issue in those two cases, federally inandated hate speech codes would seek to facilitate minority access to an arena from which minorities have often been barred.

The parallels to the FCC preferences at issue in Metro Broadcasting are especially striking. Those policies were implemented to encourage minority participation in the broadcast industry, to ensure that the needs of minority cominunities were served, and to promote the dissemination of minority viewpoints to the larger nonminority audience. ${ }^{145}$ Similarly, federally mandated hate speech regulations would seek to ensure full expression of minority viewpoints on college campuses, for the benefit of both minority students and the larger college community.

Under strict scrutiny, both the policies in Metro Broadcasting and federal hate speech regulations might be susceptible to the criticisin that they were not grounded in a remedial purpose targeting specific past discrimination proven with sufficient evidence. ${ }^{146}$ However, the Court explicitly chose to apply intermediate scrutiny to congressional enactinents, permitting limited use of benign racial criteria even if the purpose is not strictly remedial and even if the policy is designed to conbat societal discrimination rather than specific acts. ${ }^{147}$

Congressional action to achieve such broad policy objectives is not unprecedented. In approving the minority set-aside program in Fullilove, Chief Justice Burger reasoned that Congress frequently uses the Spending Power to further broad policy objectives by conditioning receipt of federal money on coinpliance with federal statutory and admimstrative directives. ${ }^{148}$ Chief Justice Burger noted that the Court had "repeatedly upheld

144. On the Court's pending review of the appropriate level of scrutiny to be applied to federally mandated affirmative action programs, and the implications of this decision for hate speech regulations, see supra text accompanying notes 19-20.

145. Metro Broadcasting, Inc. v. FCC, 497 U.S. 547, $552-56$ (1990).

146. For a discussion of this claim, see infra Part IV.B.1.b.

147. See supra notes 131-32 and accompanying text.

148. Fullilove v. Klutznick, 448 U.S. 448,474 (1980) (opinion of Burger, C.J.). 
against constitutional challenge the use of this technique to induce governments and private parties to cooperate voluntarily with federal pohicy."149 In discouraging hate speech, Congress could act both upon state governments, since public schools often receive federal funding, and upon private actors who receive federally funded research grants, student loans, and other benefits. 150

Federal hate speech legislation is not, therefore, unrealistic. ${ }^{151}$ Were the Court to extend the same deference to Congress that it did in Metro Broadcasting and Fullilove, the ensuing hate speech code would receive the benefit of the less rigorous intermediate scrutiny review.

\section{State Enactment of Hate Speech Regulations}

Even if campus hate speech regulations were implemented by a state government rather than by Congress, the intermediate scrutiny test might be appropriate. Although the Supreme Court has rejected intermediate scrutiny for preference plans that are not mandated by Congress, hate speech regulations differ in significant ways from traditional affirmative action programs. The differences alleviate at least three of Justice Powell's four objections to applying the relaxed scrutiny test in Bakke. ${ }^{152}$

First, Justice Powell asserted the impossibility of objectively determining whether a preference scheme is benign, an issue also raised by Justice O'Connor in Croson. ${ }^{153}$ Conventional preference plans confer a benefit on minority groups at the expense of the majority. They are therefore susceptible to abuse by those seeking either to advance ininorities or to harm whites. However, it is less likely that hate speech regulations could be manipulated to serve such illicit purposes. Rather than conveying a material benefit to minorities, such regulations provide only a form of vindication and a measure of protection through deterrence.

Furthermore, since hate speech regulations are not applied unless whites use hate speech against minorities, control over these regulations vests in the group that could be burdened by the regnlations rather than the

149. Id.

150. On the exercise of Congressional authority, the Fullilove Court cited Lau v. Nichols, 414 U.S. 563 (1974), where the Court upheld the constitutionality of a federal regulation applicable to public school systems receiving federal funds and prohibiting the utilization of "criteria or methods of administration which have the effect . . . of defeating or substantially impairing accomplishment of the objectives of the [educational] program as respect individuals of a particular race, color, or national origin." "Fullilove, 448 U.S. at 479 (opinion of Burger, C.J.) (quoting Lau, 414 U.S. at 568) (omission and alteration in original).

151. Concededly, the Republican Party's landslide victory during the November 1994 elections makes the passage of federal hate speech legislation unlikely for now. See, e.g., Dan Goodgame, Right Makes Might, TIME, Nov. 21, 1994, at 52 (reporting that the Republicans picked up 52 seats in the House and eight in the Senate); see also supra note 139 on recent personnel changes on the Court.

152. For a discussion of Justice Powell's four objections to the relaxed scrutiny test, see supra text aceompanying notes $88-90$.

153. See supra note 102 and accompanying text. 
groups that might be benefitted. The potential for abuse by minority groups is, therefore, minimized.

Justice Powell's second objection, that of the potential stigma that attaches to the racial group receiving special treatment, is also diminished in the hate speech context. Traditional affirmative action programs may reinforce the stereotype that people of color are unable to succeed without special help. With regard to hate speech, however, there should be no more stigma associated with seeing a speaker of racial epithets sanctioned than there is in seeing one's assailant sent to prison. Although racial minorities would receive unique protection under an asymmetrical hate speech code, protection which might engender stigma, this stigma would be no greater and probably less than that attached to special admissions policies, for example. This stigma would be even less significant when contrasted with the stigma now experienced by hate speech victims. Furthermore, stigma did not play a decisive role in the Court's Bakke, Croson, and Wygant analyses. ${ }^{154}$

The third concern, that of the burden on innocent parties, is resolved by the absence of innocent parties, at least among those penalized. Perhaps the conclusion that perpetrators of hate speech are not innocent begs the question, since any determination of guilt or innocence ultimately hinges upon the outcome of this analysis. One can argue, however, that hate speech perpetrators have little expectation of moral approval, and whatever expectation of legal approval they have could be suitably corrected with the sort of campus sensitivity and awareness campaigns that have been launched at many colleges and universities. ${ }^{155}$ Thus, university hate speech regulations would not impose an unreasonable burden on hate speech perpetrators by thwarting their expectations. ${ }^{156}$ However, whether a hate speech limitation on First Amendment rights is an unacceptable burden on those who indulge in racist speech is a more complex question that is addressed in Part IV.B below.

The fourth and final concern expressed by Justice Powell in advocating the application of a strict scrutiny test to the preference scheme at issue in Bakke suggests the need for a credible finding of past discrimination to justify such a scheme. As we have seen, this concern has evolved into a

154. See supra Parts III.A-B.

155. See, e.g., UWM Post, Inc. v. Board of Regents of the Univ. of Wis. Sys., 774 F. Supp. 1163, 1164 (E.D. Wis. 1991) (describing "Design for Diversity" campaign to "increase minority representation, multi-cultural understanding and greater diversity" throughout 26-campus university system); Devin Leonard, Welcome to the World: Freshmen Look Cultural Diversity in the Face, RECorD, Sept. 6, 1994, at CI (reporting that students at "a growing number of . . . colleges and universities nationwide are given a crash course about racial and cultural tensions during intense multicultural workshops as part of orientation").

156. When analyzing the layoff policy at issue in Wygant, Justice Powell focused on those who were negatively affected, finding that layoffs disrupted their settled expectations in.a way that hiring goals did not. See supra note 115 and accompanying text. 
requirement of sufficient evidence. ${ }^{157}$ Like the question of burdens on speech rights, this issue is addressed in the strict scrutiny discussion in Part IV.B.

As deinonstrated, hate speech regulations inplicate fewer of the fundamental considerations that influenced the Bakke Court to adopt strict scrutiny than do other affirmative action programs. Potential objections to their constitutionahty remain, however, including concerns about the reach of hate speech codes and the availability of alternatives. Moreover, because I have relied on an affirmative action justification that has traditionally been held to a strict scrutiny standard, the next Section analyzes the constitutionality of hate speech codes under strict scrutiny review. If hate speech codes pass constitutional muster under strict scrutiny, they will necessarily satisfy the intermediate scrutiny test as well.

\section{B. Hate Speech Regulations Under a Strict Scrutiny Standard}

To recapitulate, a suspect classification must be narrowly tailored to serve a compelling governmental purpose in order to pass strict scrutiny. ${ }^{158}$ Campus hate speech codes satisfy both prongs of this test.

\section{Establishing a Compelling Governmental Purpose \\ a. Compelling, According to a Broad Definition}

In Bakke, Justice Powell found that obtaining the benefits of a diverse student body was a compelling governmental purpose. ${ }^{159}$ In Fullilove, the Court upheld congressional efforts to encourage minority participation in government construction contracts. ${ }^{160}$ Although the Court did not adopt strict scrutiny and therefore did not consider whether Congress' goal was compelling under that test, the plurality opinion stated that "the MBE provision would survive judicial review under either 'test' articulated in the several Bakke opinions."161 Thus, it appears that remedying past discrimination by increasing minority opportunity in public works projects also may be a compelling governmental purpose. Lastly, in Metro Broadcasting, the Court affirmed the goal of promoting minority participation in the broadcast imdustry under an intermediate scrutiny review, noting that "the interest in enhancing broadcast diversity is, at the very least, an important governmental objective."162

By remedying past discrimination in education, government contracting, and the broadcast industry, the preference schemes in Bakke, Fullilove, and Metro Broadcasting all encouraged full integration of minor-

157. See supra text accompanying notes 108-11.

158. See supra note 91 and accompanying text.

159. See supra notes $92-93$ and accompanying text.

160. Fullilove v. Klutznick, 448 U.S. 448, 492 (1980) (opinion of Burger, C.J.).

161. Id.

162. Metro Broadcasting, Inc. v. FCC, 497 U.S. 547,567 (1990) (emphasis added). 
ities into the social, economic, political, and academic life of the nation. By remedying past discrimination in the allocation of speecli rights, campus hate speecli codes would imcrease the participation of minority students in the debate and dialogue that is central to college life. When the city of St. Paul asserted in R.A.V. that its bias crime ordinance helped to ensure "the basic liuman riglits of members of groups that have historically been subjected to discrimination," the Court responded that it "[did] not doubt that these interests [were] compelling." 163 Campus hate speech codes would similarly safeguard a basic human riglit, as well as a constitutional one, that of minorities to speak freely.

In approving the purpose of educational diversity, Justice Powell im Bakke emphasized the "robust excliange of ideas" and the "atmospliere of 'speculation, experiment and creation" " to which a diverse student body contributes. ${ }^{164}$ This interactive ideal is dependent, however, on vocal minority participation. The mere presence of minority students is insufficient; their mere presence is im fact perilously akin to tokenism. Allowing students of color to witness university life without encouraging their contribution is pointless. Yet this is the consequence of allowing campus hate speech to prohferate unchecked. The reasons for preventing this result are surely, in the conventional sense of the word, compelling.

\section{b. Compelling, According to a Narrow Definition}

Assuring equal opportunity and increasing diversity are not in themselves compelling governmental purposes approved by the Court, however. Instead, the Court has focused on remedying past discrimination. Its definition of compelling governmental purpose turns on the adequacy of the evidence proving past discrimination and whether the remedial purpose provides a logical stopping point for the preference program in question. ${ }^{165}$ As applied to hate speech codes, the relevant questions are whether state governments can show that hate speech has silenced students of color and whether hate speech codes would expire when minority students no longer suffered from a deficit of speech rights.

The answer to both these queries is yes. As discussed supra in Part II, numerous scholars have documented the harms caused by racist speech and its silencing effect on people of color. ${ }^{166}$ Measuring and momitoring this silencing effect will be difficult tasks to undertake, but ones that are well within the competence of state governments. Because state governments run our public colleges and universities, they are singularly qualified to assess the silencing effect of hate speech and to determine when it ceases to be debilitating, thereby rendering hate speech regulations obsolete.

163. R.A.V. v. City of St. Paul, 112 S. Ct. 2538, 2549 (1992).

164. Regents of the Univ. of Cal. v. Bakke, 438 U.S. 265, 312 (1978) (opinion of Powell, J.).

165. See supra notes $108-11$ and accompanying text.

166. See supra Part II.B. 
Although state governments may currently lack the necessary expertise, they are best positioned to develop the required tools and skills. At the most basic level, state governments have unique access to information on the nuniber and nature of hate speech incidents at their schools. States are also able to observe minority participation in campus activities and class discussions. State government investigation, whether accoinplished through professors or administrators, would be less intrusive than investigation by other actors. Difficult as ineasurement inay be, state governments are capable of assessing the total impact of racist speech at the institutions in their charge.

The suppression of hate speech by campus authorities will make it inore difficult to determine when hate speech ceases to be a significant problein, since there will.be no true data. Colleges and universities run the risk of seeing a dramatic increase in hate speech as soon as the artificial controls - hate speech codes-are removed. This is not a unique problem, however, and it has not hindered the Court previously. Although the past discrimination remedied in preferential college admissions programs may have been inore concrete, the remedial linnits imphed by that discrimination really are not. How can a school guarantee that admissions rates for students of color will not drop once special preferences are discontinued? And won't the data collected while preferences are in effect be biased? The same questions inay be asked of affirmative action programs in voting rights, employment, and other areas. Differences between those programs and hate speech codes are only of degree, not of kind. Perhaps even the differences of degree may be discounted, smce it is nearly as difficult to see a distinct stopping point for preferential admissions programs, for instance, as it is to see one for hate speech codes. ${ }^{167}$

In Bakke, the goal of countering society-wide discrimination was rejected because it was amorphous and beyond the competence of the University of California Regents to evaluate. ${ }^{168}$ Preventing the silencing of minorities is not an amorphous goal, however. Just as the state is competent to evaluate a school's student body, so it is conipetent to evaluate the experiences of its students. That this evaluation is difficult does not render it impossible, and difficulty has not prevented the Court froin endorsing other affirmative action programs with no distinct stopping point. ${ }^{169}$

167. Seventeen years after Regents of the Univ. of Cal. v. Bakke, 438 U.S. 265 (1978), the medical school at the University of California at Davis still gives special consideration to applicants of color. See Bernstein, supra note 18, at B8 (discussing the current program). Admittedly, for critics of affirmative action, this is likely another reason to terminate such programs immediately-whatever the result.

168. Bakke, 438 U.S. at 307-10 (opinion of Powell, J.).

169. See, e.g., Metro Broadcasting, Inc. v. FCC, 497 U.S. 547 (1990). The Metro Broadcasting Court held that the minority ownership policies at issue were appropriately limited in extent and duration, but identified only the following sufficient safeguards: future re-evaluation of the need for the policies was assured because the relevant congressional appropriations acts were of finite duration; Congress had continued to hold hearings on minority ownership; the FCC was to report annually on the 
Though some students of color are able to resist the silencing effect of hate speech, there is little dispute that hate speech tends to silence minorities. The pertinent question is how we as a legal community, and a society, will respond. Mari Matsuda warns that "[o]fficial tolerance of racist speech in [the university] setting is more harmful than generalized tolerance in the community-at-large." 170 Those harmed include the perpetrators, who may take the lesson that they can "get away with it" to less forgiving contexts; the victims, who will have been disappointed once again by the Establishment; and the fragile ideals of inclusion, education, knowledge, and ethics. ${ }^{171}$ Matsuda comments that "[1]essons of cynicism and hate [will] replace lessons in critical thought and inquiry."172

Effectively regulating hate speech would not necessitate the boundless legislative latitude that concerned the Court in Wygant and Croson. Those cases imvolved unsubstantiated assertions of general discrimination. By comparison, campus hate speech codes could be confined in their scope to specified imstances of discrimination in the form of racial imsults. Moreover, the direct burden would fall only on student perpetrators acting with complete knowledge of the attendant legal sanctions.

It is possible, however, that even this burden is too onerous, that the resulting diminishment of free speech rights is unacceptable however compelling the governmental purpose. The next Section turns to this issue.

\section{The Narrow Tailoring Requirement}

Strict scrutiny's narrow tailoring requirement performs two functions. It ensures that a suspect classification serves no other, illicit goals in addition to the stated and approved one, ${ }^{173}$ and it guards against the imposition of undue burdens on the innocent parties who shoulder the costs of preference programs. ${ }^{174}$

\section{a. Illicit Goals and Undue Burdens}

The concern that hate speech codes may be used to serve illicit goals deserves only slight attention. In Croson, the Court acknowledged the argument that affirmative action programs usually "imvolve a choice made by dommant racial groups to disadvantage themselves" and the programs,

effects of the preference system; administrative and judicial review of all FCC decisions would ensure frequent revisiting of the merits of the policies. Id. at 594-96. The Court found that the goal of achieving greater programming diversity "carries its own natural limit, for there will be no need for further minority preferences once sufficient diversity has been achieved." Id. at 596.

170. Matsuda, supra note 8 , at 2371 .

171. Id.

172. Id.

173. See, e.g., City of Richmond v. J.A. Croson Co., 488 U.S. 469, 493 (1989) (opinion of O'Connor, J.) (stating that the strict scrutiny test "ensures that the means chosen 'fit' [the] compelling goal so closely that there is little or no possibility that the motive for the elassification was illegitimate racial prejudice or stereotype").

174. See supra text accompanying notes 113-15. 
therefore, are less likely to result from abuses of authority and impermissible motives. ${ }^{175}$ Justice O'Connor demied the city of Richmond the benefit of this assumption, however, since, as she scrupulously noted, African Americans comprised approximately $50 \%$ of the city's population and held five of the nine seats on the city council. ${ }^{176}$ Whatever the substantive merits of this logic, it is largely irrelevant to our analysis since hate speech regulations, if enacted in the near future, would likely be passed by state governments that are not dominated by minorities. This is so even though most current advocates of hate speech regulations are people of color. ${ }^{177}$

The second function of the narrow tailoring requirement, its concern for the costs borne by those who may not themselves have contributed to the discrimination being remedied, is more pertinent. Two primary questions inust be asked: who pays the costs of hate speech regulations, and is that burden too oppressive?

The first question receives a satisfactory answer in the singular nature of hate speech regulations. Unlike conventional preference plans, such regulations would not impose burdens arbitrarily simce only actual perpetrators of racist speech would be directly penalized. In Bakke, Wygant, Croson, and other affirmative action cases, complamants were selected to bear remedial costs based on their occupation, their seniority, their race, or other largely randoin factors. In contrast, only students who chose of their own volition to use racist slurs and insults would be targeted by hate speech regulations. Hence, regulation of hate speech does not raise the issues of individual culpability and individual worthiness that have occupied the Court in affirmative action cases. Each student directly benefitted and each student directly penalized will be deserving, at least to the extent of having heard or uttered a racial epithet.

As is true of all speech limits, however, there is the danger of indirect penalties. Implementation of such codes might "chill" permissible speech that does not rise to the level of hate speech. If so, then students who are thereby silenced would also be penalized, increasing the costs of hate speech regulations. ${ }^{178}$

At its worst, this chilling effect would silence speakers who did not use racial insults. Requiring innocent parties to bear part of the cost of a traditional affirmative action program is not by itself fatal to the program. As Chief Justice Burger noted about the set-aside scheme in Fullilove, "It is not a constitutional defect in this program that it may disappoint the expec-

175. Croson, 488 U.S. at 495 (opinion of O'Connor, J.).

176. Id. at 495-96 (opinion of O'Connor, J.).

177. See supra note 72 and accompanying text.

178. A federal district court responded to this concem in Doe v. University of Mich., $721 \mathrm{~F}$. Supp. 852 (E.D. Mich. 1989), in which a graduate psychology student specializing in biopsychology alleged that the university's hate speech policy might penalize him for exercising his right to enter into classroom discussion about controversial theories positing biologically based differences between sexes and races. The court held that the policy was vague and overbroad. Id. at 866-67. 
tations of nonminority firms. When effectuating a limited and properly tailored remedy to cure the effects of prior discrimination, such 'a sharing of the burden' by innocent parties is not impermissible."179 However, restrictmg the speech of innocent parties is more significant than denying them a contracting opportunity. The chilling effect of hate speech regulations raises serious First Amendment questions.

Nevertheless, vagueness and overbreadth concerns are not unique to late speech codes and can be addressed through careful drafting. Professors Richard Delgado and David Yun argue that it is technically feasible to draft constitutional campus antiracism rules. ${ }^{180}$ Delgado and Yun suggest that such rules could prohibit expressions of racial hatred and contempt directly, or they could regulate behavior currently actionable in tort. ${ }^{181}$ Either approach would satisfy current constitutional requirements. According to Delgado and Yun, all we lack is the will. ${ }^{182}$

If they are instituted, the benefit flowing from campus hate speech codes would reach not only the victims of hate speech, who would see justice done, but also the entire community, which would benefit from the deterrent effect. However, this added benefit would not increase the costs of a hate speech code. In situations involving conventional affirmative action programs, extending benefits to those who have not theinselves suffered froun discrimination causes concern because of the corresponding additional burden on innocent parties. In contrast, campus hate speech regulations would not exact an additional price for the added benefit accrued by nonvictims. Those who engage in hate speech would not be penahized more harshly in order to benefit the community since this benefit, the deterrent effect, is built into the sanction that would be imposed in any case.

Other issues related to who carries the burden of preference programs are inapplicable to the hate speech context. The Court's emphasis on flexibility, exemplified by a waiver of the preference where the burden on the

179. Fullilove v. Klutznick, 448 U.S. 448, 484 (1980) (opinion of Burger, C.J.) (citations omitted).

180. Delgado \& Yun, supra note 60 , at 886.

181. Id. The direct approach would combine two lines of attack. The first would be a prohibition against "severe, face-to-face invective calculated seriously to disrupt the victim's ability to function in a campus setting." Id. This provision could be "tailored to capture the content of any recognized First Amendment exception, such as fighting words or workplace harassment." Id. at 886-87 (footnote omitted). The second provision would enhance the punishment for any offense proven to have been committed with a racial motivation. Id. at 887 .

Delgado and Yun's altemative approach would be based on an existing tort such as intentional infliction of emotional distress. The race of the victim would function as "a 'special factor' calling for mereased protection, as current rules and the Restatement of Torts already provide." Id.

Note, however, that Delgado and Yun advocate a race-neutral approach to campus hate speech codes in contrast to the asymmetrical scheme described in this Comment. Id. at 886-87.

182. Id. But see Corry v. Leland Stanford Junior Univ., No. 740309 (Cal. Super. Ct. Feb. 27, 1995) (order granting preliminary injunction) (rejecting constitutional challenge to $C_{A A}$. EDuc. CODE $\S 94367$, which prohibits private universities from disciplining students for specch that would be protected by the First Amendment off-campus, and invalidating Stanford's narrowly drawn hate speech code, which was based on the "fighting words" exception). 
majority group would be unfair, ${ }^{183}$ is meaningless since no disciplinary action would be taken unless one student racially insulted another. It is difficult to imagine what would excuse racist speech, but any extenuating circuinstances could be taken imto account by canıpus authorities.

The second and final question, whether the harm caused to minorities justifies the burden imposed on student perpetrators, is more intractable. Ostensibly, censoring a student who has called another a "nigger" - and deterring others from so indulging theinselves in the future-is less onerous than being denied admission in the first place, which, realistically, is the result of all school affirmative action progranis for some applicants. ${ }^{184}$ Although the Davis plan was struck down in Bakke, racial minorities routinely receive special consideration at many colleges and universities. By comparison, preferential layoff schemes like the one in Wygant do not survive strict scrutiny because they impose too heavy a burden on the innocent. However, being prevented from using racial insults seeins less drastic to an individual than losing one's job. It is likely that most people consider their job more important than their freedom to insult people of color. This choice seems particularly clear when one considers that the burden imposed on perpetrators would be minimal. A narrowly drafted speech code would not proscribe, for example, non-intimidating speech on the subject of race and ethnicity in a neutral forum. On an individual level, therefore, hate speech codes do not impose a disproportionate burden.

\section{b. Alternatives to Hate Speech Codes: The Usual Candidates}

First Amendment absolutists will quickly object, however, that hate speech regulations impose their most serious burden not on individual perpetrators but on speech rights generally. By extension, hate speech regulations would not be narrowly tailored if there were a means of discouraging hate speech that was less intrusive in terins of our First Amendment values. The usual candidates for such alternative measures include increased speech on the part of the victims, campus sensitivity and awareness campaigns to

183. See, e.g., Fullilove v. Klutznick, 448 U.S. 448, 487 (1980) (opinion of Burger, C.J.) ("It is significant that the administrative scheme provides for waiver and exemption.").

184. The effect of an affirmative action program is always the same, no matter how the program operates in its particulars. In Bakke, Justice Brennan made this point in his discussion of the differences between the Davis affirmative action plan and other policies:

In any admissions program which accords special consideration to disadvantaged racial minorities, a determination of the degree of preference to be given is unavoidable, and any given preference that results in the exclusion of a white candidate is no more or less constitutionally acceptable than a program such as that at Davis. ... There is no sensible, and certainly no constitutional, distinction between, for example, adding a set number of points to the admissions rating of disadvantaged minority applicants as an expression of the preference with the expectation that this will result in the admission of an approximately determined number of qualified minority applicants and setting a fixed number of places for such applicants as was done here.

Regents of the Univ. of Cal. v. Bakke, 438 U.S. 265, 378 (1978) (Brennan, White, Marshall, and Blackmun, JJ., concurring in the judgment in part and dissenting in part). 
ameliorate race relations, the creation of forums for discussion of controversial race-related issues, even counseling. ${ }^{185}$

Nadine Strossen cites Texas v. Johnson ${ }^{186}$ as a reaffirmation of the "time-honored principle" that the appropriate response to offensive speech is not censorship but rather the exercise of our own speech rights. ${ }^{187}$ The Johnson Court advised those who were offended by the burning of the American flag that "[t]he way to preserve the flag's special role is not to punish those who feel differently about these matters. It is to persuade them that they are wrong."188

Calvin Massey cites the civil rights moveinent of the 1960 s as an important example of how free speech can be put to good use, particularly in the nonrational, symbolic form that some hate speech opponents seek to eradicate. ${ }^{189}$ Civil rights activist Michael Meyers has stated the argument for "counterspeech" more urgently:

As a former student activist, and as a current black militant, [I] believe[] that free speech is the minority's strongest weapon. . . . $[\mathrm{P}$ ]aternalism [and] censorship offer the college student a tranquilizer as the antidote to campus and societal racism. What we need is an alarm clock. ... What we need is free speech . . . and inore free speech! ${ }^{190}$

\section{c. The Usual Candidates Rejected}

Although proponents of hate speech regulations have acknowledged the appeal of the counterspeech argument, ${ }^{191}$ they argue that counterspeech is inadequate. Charles Lawrence writes, "Most blacks-unlike many white civil libertarians-do not have faith in free speech as the most important vehicle for liberation. The first amendment coexisted with slavery, and we still are not sure it will protect us to the same extent that it protects whites."192 Lawrence eschews any reliance on the marketplace of ideas and the behef that only the best ideas will gain currency. "Racism," he writes,

185. See, e.g., Strossen, supra note 7, at 562-64; see also Delgado, Campus Antiracism Rules, supra note 1, at 361; Matsuda, supra note 8 , at 2350 .

186. 491 U.S. 397 (1989).

187. Strossen, supra note 7 , at 562 .

188. Texas v. Johnson, 491 U.S. at 419.

189. Massey, supra note 7 , at 112 (criticizing as untenable the distinction made by "accommodationists" between rational discourse, which would receive constitutional protection, and irrational discourse, which would be proscribed).

190. Michael Myers, Banning Racist and Other Kinds of "Hate" Speech on the College Campus (outline for a debate with John A. Powell at Hofstra University, Hempstead, Long Island, Jan. 25, 1990), quoted in Strossen, supra note 7, at 487 \& n.10 (alterations in original). When Myers made this statement, he was a member of the ACLU's National Board of Directors and its Affirmative Action Officer.

191. See, e.g., Matsuda, supra note 8 , at 2350 \& n.158 (noting the argument that the best means of combatting racist oppression is the right of protest-the tactic of "creative tension" and "causing offense").

192. Lawrence, If He Hollers, supra note 8, at 466. 
"is an epidemic infecting the marketplace of ideas and rendering it dysfunctional."193

As for the other alternatives, the high number of racist incidents provides empirical evidence that education and discussion do not suffice, whether alone or in combination with counterspeech. Another option exists: augmenting the speech rights of mimorities rather than restricting the speech rights of hate speech perpetrators. Such a program would more closely resemble traditional affirmative action programs, through which minorities are afforded a benefit denied to the majority. In addition, there would be no ostensible infringement of First Amendment rights.

It is difficult to imagime, however, what form such a preference would take. Its efficacy is similarly doubtful. The state might provide, for example, extra funding to minority student organizations. However, in some ways the state already does so, without the result of curbing hate speech. To the extent that there are minority student groups on many college campuses but no such groups for white students, ${ }^{194}$ and to the extent that these minority groups receive public funding, they are given a preference that often results in imcreased expressive activity. Unfortunately, despite the existence of such groups, hate speech continues to be a problem on campuses throughout the country. Most, if not all, of the incidents described in the Introduction to this Comment occurred at campuses that supported minority student organizations at the time of the imcident, to no avail.

In fact, it may be that the increased presence of students of color at these schools, and their increased expressive activity, contribute to the escalating racial tensions of which hate speech is a manifestation. As has often been the case for minorities, raising one's voice sometimes attracts unwanted attention in the form of resentment. As a result, minorities are caught in a catch-22.

The appeal of a program that would enhance the speech opportunities of students of color is chimerical on another level. Speech rights, like other resources, are often limited. ${ }^{195}$ The government may not be able to increase

193. Id. at 468. Lawrence is even more explicit: "The American marketplace of ideas was founded with the idea of the racial inferiority of non-whites as one of its chief commodities, and ever since the market opened, racism has remained its most active item in trade." Id.

194. But see Devin Leonard, The Faces Are Familiar: Ethnic Clubs Booming on Campus, Record, June 7, 1994, at Bl (noting that white students have recently formed their own ethnic clubs at colleges and universities); Lilhan Salazar Leopold, Anglo-Formed Student Clubs Stir Animosity, S.D. UnionTRB., Mar. 15, 1993, at B3 (reporting controversy surrounding the formation and attempted formation of the All-American Club and the European Club-originally ealled Caucasians United-at two high schools); Not for Whites Only, TMME, Oct. 14, 1991, at 33 (describing the creation of the EuropeanAmerican Club at an Anaheim, California, high school); Valerie Richardson, The Greening of Multiculturalism. WASH. TIMEs, May 10, 1993, at A1 (observing that the proposed formation of an Irish-American Students Association at Stanford University "went over like Prince Charlcs meeting the Irish Republican Army").

195. The Court has addressed this point in its cases dealing with the television and radio broadcasting industries. See, e.g., Metro Broadcasting, Inc. v. FCC, 497 U.S. 547, 566-67 (1990) (noting that the Court has long recognized that " "[b]ecause of the scarcity of [electromagnetic] 
the speech activities of one group without decreasing those of another. In the case of public funding, support for organizations such as the African American Students Association or the Chicano Students Association necessitates correspondingly lower levels of support for other student groups, including the White Students Association if one exists. Thus, discouraging hate speech by augmenting the speech rights of minorities would incur costs just as hate speech codes do but with little assurance of success.

Similarly, increased stateinents from campus administrators or professors would likely have only slight influence. Such stateinents might take the form of diversity workshops or multiculturalism programs-the same sort of activities that have been conducted in recent years on campuses across the country ${ }^{196}$ without coming close to eliminating racist speech.

Racial insults draw their venoin froin centuries of slavery and racial hostility. If and when race relations improve so that students no longer need special protection, then hate speech regulations will no longer be justified. Narrowly tailored regulations would provide for this eventuality. Until then, however, we should not rely only on education, increased funding, and moral suasion.

Strict scrutiny requires that preference programs be narrowly tailored to serve a coinpelling governmental purpose. It does not require such programs to be so narrowly tailored that they cease to serve their purpose entirely. If we take as our purpose the remedying of discrimination in the allocation of speech rights, then the only effective ineans toward that end is hate speech regulation. If the courts find that hate speech codes fail the strict scrutiny test because they are not narrowly tailored, then the narrow tailorimg requirement will have wholly swallowed the strict scrutiny standard. At that point, strict scrutiny will truly be " 'strict' in theory and fatal in fact. ${ }^{.197}$

Instead, the narrow tailorimg requirement should be considered satisfied if no alternative to the preference program in question adequately serves the program's purpose. As the only program capable of achieving equality in speech rights, hate speech regulations are narrowly tailored. Such regulations survive the second prong of the strict scrutiny test as well as the first, and are therefore a valid form of affirmative action. This outcoine preserves speech rights to the greatest extent possible but subordinates the speech rights of the inajority to those of minorities, who have long paid the costs of hate speech with their silence. Reinedying this deficit is

frequencies, the Government is permitted to put restraints on licensees in favor of others whose views should be expressed on this unique medium' ') (quoting Red Lion Broadcasting v. FCC, 395 U.S. 367, 380 (1969)) (alterations in original); FCC v. Pacifica Found., 438 U.S. 726, 748 (1978) (stating that broadcasters "must give free time to the victims of their criticism").

196. See supra note 155.

197. This phrase was first used by Gcrald Gunther, The Supreme Court, 1971 Term-Foreword: In Search of Evolving Doctrine on a Changing Court: A Model for a Newer Equal Protection, 86 HARv. L. REv. 1, 8 (1972). 
uniquely the province of the Fourteenth Amendment's Equal Protection Clause.

\section{$\mathrm{V}$ \\ Weighing Freedom and EQUality}

Application of the strict scrutiny analysis to speech restrictions is not new. ${ }^{198}$ In fact, the city of St. Paul argued unsuccessfully in R.A.V. that its bias-motivated crime ordinance was valid because it survived strict scrutiny. ${ }^{199}$ The purpose of this Comment, however, has not been to import a test from equal protection law so much as it has been to adopt the entire body of that law, and to consider hate speech codes in light of the concerns that drive that law.

Critics of this solution will argue that this Comment only answers the old question with the currently fashionable answer. That question is whether the First Amendment or the Fourteenth Amendment should prevail. The fashionable answer, at least since the publication of Richard Delgado's provocative Words That Wound, ${ }^{200}$ is that equality trumps free speech. ${ }^{201}$ However, proponents of hate speech regulations generally invoke the Fourteenth Amendment in pursuit of equality in education. Instead, the proposed solution seeks equality in expression. The apparent tension between the First and Fourteenth Amendment dissolves when the governmental interest pursued is free speech for all.

When one person's exercise of speech rights impairs the exercise of another's, the resulting inequity is justified under neither the First nor the Fourteenth Amendment. The Supreme Court has acknowledged as much in another context - that of the "heckler's veto."202 Under this doctrine, hostile audiences are prevented from interfering with the First Amendment

198. See, e.g., Perry Educ. Ass'n v. Perry Local Educators' Ass'n, 460 U.S. 37, 45 (1983) ("For the State to enforce a content-based exclusion [in a public forum] it must show that its regulation is necessary to serve a compelling state interest and that it is narrowly drawn to achieve that end.") (citing Carey v. Brown, 447 U.S. 455, 461 (1980)).

199. R.A.V. v. City of St. Paul, 112 S. Ct. 2538, 2549 (1992). The Court acknowledged that the city's purpose was compelling but found that content discrimination was "clearly" not necessary since an ordinance not limited to "favored topics" would have been equally effective. Id. at 2549-50. For a discussion of the effeetiveness of alternatives to hate speech regulations, see supra text accompanying notes $185-96$.

200. Delgado, supra note 8 .

201. The recent popularity of hate speech regulations among some scholars is not to be mistaken for judicial approval. In the first two cases to consider campus hate speech regulations, separate federal district courts held that the disputed regulations were uncoustitutional under the First Amendment. UWM Post, Inc. v. Board of Regents of the Univ. of Wis. Sys., 774 F. Supp. 1163 (E.D. Wis. 1991) (finding that university hate speech code was invalid under the fighting words doctrine and striking it down as overbroad and vague); Doe v. Univ. of Mich., 721 F. Supp. 852 (E.D. Mich. 1989) (holding that university hate speech policy was overbroad and vague and grounding the decision in a finding of content discrimination); see also Corry v. Leland Stanford Junior Univ., No. 740309 (Cal. Super. Ct. Feb. 27, 1995) (order granting preliminary injunction), discussed supra note 182.

202. This phrase was introduced by Harry Kalven, Jr., in THE NEGRo AND tHE First AMENDMENr $140-45$ (1965). 
rights of an unpopular speaker ${ }^{203}$ Although there has been debate about the extent of this protection, ${ }^{204}$ the Court has concluded that hostile audiences usually will not be allowed to assert their speech rights to the detriment of the speech rights of their targets. ${ }^{205}$

At first glance, the heckler's veto cases seem to provide more ammunition for opponents of hate speech regulations. In Terminiello v. Chicago, ${ }^{206}$ the Court emphasized its commitment even to unpalatable speech:

[Free speech] may indeed best serve its high purpose when it induces a condition of unrest, creates dissatisfaction with conditions as they are, or even stirs people to anger. Speech is often provocative and challenging. It may strike at prejudices and preconceptions and have profound unsettling effects as it presses for acceptance of an idea. That is why freedom of speech, though not absolute, is nevertheless protected against censorship or punishment, unless shown likely to produce a clear and present danger of a serious substantive evil that rises far above public inconvenience, annoyance, or unrest. ${ }^{207}$

Thus, one could rely on Terminiello to argue that racist speech should not be censured even though it provokes unrest or anger. However, like other arguments supporting freedom of speech, the ideas articulated in the hostile

203. See Terminiello v. Chicago, 337 U.S. 1 (1949). Like many of the cases involving heckler's vetoes, Terminiello involved a municipal breach of the peace ordinance. Petitioner was convicted under the ordinance after making a speech criticizing various political and racial groups. Outside the auditorium in which he spoke, an angry crowd of about one thousand people gathered to protest the speech and caused several disturbances. In striking down the ordinance, the Court commented that "[t]he vitality of civil and political institutions in our society depends on free discussion. . . . Accordingly a function of free speech under our system of government is to invite dispute." Id. at 4.

204. See Feiner v. New York, 340 U.S. 315 (1951). The Feiner Court sustained a disorderly conduct conviction against a speaker who had made inflammatory remarks about the President, the American Legion, the mayor, and other local officials at an open-air meeting. In ruling, the Court stated,

We are well aware that the ordinary murmurings and objections of a hostile audience cannot be allowed to silence a speaker, and are also mindful of the possible danger of giving overzealous police officials complete discretion to break up otherwise lawful public meetings. ... But we are not faced bere with such a situation. It is one thing to say that the police cannot be used as an instrument for the suppression of unpopular views, and another to say that, when as here the speaker passes the bounds of argument or persuasion and undertakes incitement to riot, they are powerless to prevent a breach of the peace.

Id. at 320-21.

205. See Cox v. Louisiana, 379 U.S. 536 (1965) (reversing the breach of the peace conviction of a civil rights demonstrator who refused to obey a police order to disperse despite the potential for a disturbance involving onlookers); Edwards v. South Carolina, 372 U.S. 229 (1963) (similar); see also Glasson v. City of Louisville, 518 F.2d 899, 905-06 (6th Cir.), cert. denied, 423 U.S. 930 (1975) (finding that the police had violated the constitutional rights of a demonstrator by renoving her sign, which was critical of the Nixon Administration, in order to avoid a disturbance); In re Kay, 1 Cal. 3d 930, 941 (1970) (en banc) (recognizing that "the state retains a legitimate concern in ensuring that some individuals' unruly assertion of their rights of free expression does not imperil other citizens' rights of free association and discussion").

206. 337 U.S. 1 (1949).

207. Id. at 4 (citation omitted). 
audience cases cut both ways. We should not assume that the role of the speaker will be taken by the racist. If, mstead, the speaker is a person of color, and the hostile audience is composed of hate speech perpetrators who seek to silence the speaker, then Terminiello and its progeny suggest that the state should act to restram the hate speech perpetrators and to protect the First Amendment rights of the speaker. Hate speech codes perform just this function.

We cannot know what people of color would say given equal speech opportunities. Would their message be more or less "unsettling" than racist speech? Which would create more "dissatisfaction with conditions as they are"? Which would more powerfully strike at "prejudices and preconceptions"? We will not know until we can ensure equal time and opportunity to minority speakers. The heckler's veto cases acknowledge the need for equal speech rights. Until we can guarantee such rights, our so-called freedoin of speech is illusory: there can be no freedom of speech without equality of speech. On college cainpuses especially, where discussion is the model for growth and learning, equality in the allocation of speech rights is critical. Campus hate speech regulations are properly considered, for these reasons, under the rubric of the Fourteenth Amendment.

The traditional argument against this type of governmental intervention asks for our faith in dialogue, communication, speech, and debate. If we prevent all obstructions to freedom of expression, the argument goes, then right and truth will eventually prevail. Opponents of hate speech codes gamble that racist speech will eventually disappear so long as we safeguard our speech rights. In this game, however, only minorities have been asked to ante up. If, as experience teaches, free speech is insufficient to stop hate speech, then ininorities will continue to lose.

In response to Charles Lawrence's criticism of the scarce protection that the First Amendment has so far provided to people of color, ${ }^{208}$ Nadime Strossen argues that the First Amendment is more robust than it used to be. She explains, "In short, although slavery coexisted with the theoretical guarantees enunciated in the [F]irst [A]mendment, slavery did not coexist with the judicially enforceable version of those guarantees that emerged only after World War I."209 Perhaps, as Strossen claims, slavery would have been abolished more quickly had the First Amendment then had teeth, but the fact that freedom of speech has such recent origins is itself telling.

Defenders of the First Amendment assert its priority over other Constitutional provisions, citing its preeminent place in the Bill of Rights. However, if freedom of speech as we know it did not develop until well into the twentieth century, then the Fourteenth Amendment, passed in 1868 after the end of the Civil War, is in fact much older. Although chronology is not

208. See supra note $192-93$ and accompanying text.

209. Strossen, supra note 7 , at 566 . 
dispositive of the question of priority, neither can First Amendment absolutists claim the authority of long settled doctrine.

Along with the Thirteenth Amendment, which abolished slavery, the Fourteenth was passed specifically to protect African Americans. It included in its provisions not only the Equal Protection Clause but the Due Process Clause, through which the First Amendment is applied to the states. This implies a special solicitude for the speech rights of the newly freed slaves. If so, equality provided much of the impetus for the subsequent expansion in First Amendment doctrine. ${ }^{210}$

In his discussion of the First and Fourteenth Amendments, Charles Lawrence relates a story told to him by John Powell, an African American who was then the National Legal Director of the ACLU. The story takes place over a Thanksgiving dinner. Powell's family is vegetarian, and Powell's children asked which of the two dressings on the table was the vegetarian dressing. One of the hosts, pointing, said, "This is the regular dressing, and the other is the vegetarian dressing."211 To many Americans, the First Amendment is the "regular" amendment, and the Fourteenth Amendment is the "vegetarian" amendment- "a special amendment for a minority of different people."212

In truth, equality concerns us all. Unless we respect difference, we are all unequal, and we are all vulnerable to discrimination and prejudice. Although the Fourteenth Amendment was drafted on behalf of the newly freed slaves, its language encompasses all Americans. Its protections, like those of the First Amendment, extend to everyone. We cannot embrace one amendment to the exclusion of the other, however. Neither is meaningful so divorced. The First Amendment's guarantee of free speech must be read in tandem with the Fourteenth Amendment's guarantee of equality. Far from being irreconcilable with freedom of speech, the Fourteenth Amendment's Equal Protection Clause provides a justification for hate

210. Akhil Amar suggests that the extent of this result may have been unforeseen: Indeed, the very vigor with which the Supreme Court now enforces the First Amendment-and much of the rest of the Bill of Rights-against Congress is largely due to the incorporation of the Bill of Rights against states. Early critics of incorporation feared it would tempt judges to water down the Bill's commands; but in fact the result has generally been the opposite.

Amar, supra note 45, at 152 n. 157 .

Amar argues that consideration of the Reconstruction Amendments by the R.A.V. Court would have resulted in "sharper and more persuasive opinions." Id. at 160. As he puts it, "[the Justices] all seemed to have forgotten that it is a Constitution they are expounding, and that the Constitution contains not just the First Amendment, but the Thirteenth and Fourteenth Amendments as well." Id. at 125.

Although Amar rejects a Fourteenth Amendment justification for hate speeeh, he concludes that racist speech might be regulated under the Thirteenth Amendment as one of the "badges and incidents of the slavery system." Id. at 155-60. But see Alex Kozinski \& Eugene Volokh, A Penumbra Too Far, 106 HARV. L. REv. 1639 (1993) (criticizing Amar's thesis on the bases of plausibility, vagueness, and unintended consequences).

211. Lawrence, If He Hollers, supra note 8, at 473.

212. Id. at 474. 
speech regulations that preserves First Amendment values and extends speech rights to all.

\section{CONCLUSTON}

Racist speech is repugnant to many if not most Americans, whatever their race or ethnicity. So too-rightfully-is censorship. I have argued that the twin goals of eliminating hate speech and protecting free speech are not inconsistent. By prohibiting hate speech, we can create greater speech opportunities for groups that have been traditionally disadvantaged in their speech rights.

Hate speech im colleges and universities is especially disheartening because campus communities are among our most enlightened. Even if a young student of color makes it to college, her thoughts, ideas, and opinions may be silenced by racial imsults. Because hate speech silences, the illusory "freedom" of speech that protects hate speech necessarily silences hate speech victims. In the same way, "equal" protection is hollow when it ignores the long history of discrimination agaimst people of color. Courts have acknowledged the persuasive force of this argument in the economic, political, and educational arenas. We should now focus the weight of this logic on speech rights. Just as affirmative action programs remedy past discrimination in the areas of public contracting, votimg rights, and college admissions, hate speech regnlations would remedy past discrimination in the allocation of speech opportunities. As the cost of true freedom, hate speech codes will exact a steep but necessary price. The payback is longterm equality of expression for all speakers, regardless of race or ethnicity.

It may be that we lack the will to impose hate speech regulations upon ourselves. The rising tide of conservative voices calling for an end to affirmative action programs suggests nothing less. ${ }^{213}$ The bleak alternative, however, seems to be nothing more than the status quo or, at best, slow, fitful improvement measured im inches and fractions thereof. We must recognize as a society that it is only by silencing the silencers that we can finally give voice to peoples of all colors.

According to our First Amendment paradign, resolution of the hate speech question began when debate began. According to the Fourteenth Amendment, we will find our answer only after we have heard from many different speakers of all races and ethnicities, both sexes, every political persuasion, and all walks of life. Most important, all must participate equally.

213. See supra notes $13-19$ and accompanying text. 